\title{
DESIGN AND IMPLEMENTATION OF A COMMUNITY BASED SUSTAINABLE DEVELOPMENT ACTION RESEARCH METHOD
}

\author{
Susan Krumdieck \\ Associate Professor, Department of Mechanical Engineering, Private Bag 4800, University of \\ Canterbury, Christchurch, New Zealand \\ Michael Dale \\ Post Doctoral Research Fellow, Global Climate \& Energy Project, 473 Via Ortega, Stanford \\ University, Stanford, CA
}

\author{
Shannon Page \\ New Zealand \\ Corresponding Author: Susan Krumdieck \\ Email: susan.krumdieck@canterbury.ac.nz , \\ Tel: $\quad+6433642987 \times 7249$ \\ Fax: $\quad+6433642078$
}

Lecturer, Faculty of Environment, Society and Design, PO Box 84, Lincoln University, Lincoln,

Susan Krumdieck earned her Masters in Energy Systems Engineering at Arizona State University and her $\mathrm{PhD}$ in Mechanical Engineering from University of Colorado at Boulder. Susan's research includes thin material processing using metalorganic chemical vapor deposition, geothermal and waste heat power generation, low energy transportation, and renewable energy. For the past 12 years at Canterbury University, she has pursued a vigorous research program aimed at developing new engineering capabilities to address the issues and risks of un-sustainable energy and resource use and environmental impacts. She is now spearheading an international effort to establish the field of Transition Engineering which focuses on change of existing systems to reduce un-sustainable energy use, particularly in transportation, buildings and urban form.

Michael Dale holds a Masters Degree in Physics and Philosophy from the University of Bristol, UK. He undertook his Ph.D. in Mechanical Engineering with the Advanced Energy and Material Systems (AEMS) Laboratory at the University of Canterbury, New Zealand. His doctoral thesis was "Global Energy Modelling - A Biophysical Approach" which married net energy analysis with systems dynamic modelling to study the interaction of the economy with the energy sector. He joined the Global Climate and Energy Project at Stanford University as a Post-doctoral Researcher in February 2011. Michael's research interests include the long-term, large-scale dynamics of the energy-economy system, the energy-return-on-investment (EROI) of energy production technologies and the transition from fossil fuels to renewable energy sources.

Shannon Page earned his BSc(Hons) in Physics and $\mathrm{PhD}$ in Mechanical Engineering from University of Canterbury with the Advanced Energy and Material Systems (AEMS) Lab. He joined the faculty at Lincoln University in 2011. Shannon's research interests include sustainable energy systems, electricity generation and network modelling, transportation energy and carbon emissions reduction. 


\title{
Design and implementation of a community based sustainable development action research method
}

\begin{abstract}
:
Local community groups have been forming around taking action on the issues of Peak Oil and Climate Change. People perceive a risk to their security and are alarmed by the lack of action at the government level. Sustainability of local communities, their infrastructure and social assets is a field that should gain as much attention from the engineering professions as green technology. This paper reports the development of the TransitionScape methodology and implementation in a weekend workshop in a rural town in New Zealand. The methodology was designed from first principles of action research and group psychology. The objective of the workshop was to transition the community from a point of fear and concern to a state of action by initiating community-generated projects that mitigate the risk of external un-sustainability. The workshop was a success, with numerous projects resulting from the one weekend. We recommend that Transition Engineering practitioners could deliver this workshop at a reasonable cost to communities around the world.
\end{abstract}

Keywords: Community, Transition, Local Initiatives, Action Research, Engineering, Projects 


\section{INTRODUCTION}

The theoretical foundation of this work is that engineers need to take on a much more proactive role in community level development in order to manage the risks of unsustainable resource depletion and environmental degradation. Our research group has investigated all of the so-called green technologies such as carbon capture and storage, hydrogen, renewable energy, biofuels and electric vehicles. Our proposition is that development to reduce un-sustainable resource use and environmental impacts will not be achieved through new resources being utilized, but rather through change of existing systems to use less energy and resources. Our hypothesis is that a new field of engineering is emerging, Transition Engineering, which deals directly with change of energy and material systems to reduce demand, increase adaptive capacity, and manage risks (Krumdieck, 2011). One of the critical areas for Transition Engineering work is at the community level (Krumideck, 2011a). Most professional engineers are employed at the corporate or government level. The challenge in this work is to apply the art of engineering at the community lavel by designing a method to generate community-initiated development projects that have measurable sustainability outcomes.

This paper outlines a method of participatory community planning that was undertaken with the aims of (1) providing the facts about Peak Oil, Global Climate Change, Electric Power System, (2) help people explore their individual and group responses and (3) provide a forum to generate projects in the community for sustained value, resilience and adaptation. This method was trialled at the "Climate Disruption. Transition Towns. One Response" weekend forum organised by the Natural Heritage Society Oamaru for over fifty participants from the town of Oamaru, New Zealand and surrounding communities. The method used was adapted from Tippet's DesignWay ecological planning tool to generate a wide variety of community-based projects (Tippets, 2007). 


\section{The Problems of Peak Oil and Climate Change}

The environmental and resource problems facing human society such as Climate Change and Peak Oil are are driving a new type of local activism. The risk of increasing green house gas levels in the atmosphere has been recognised for more than a century. In 1896 Arrhenius, a prominent chemist, warned that burning of coal in industry could cause temperature rise over the coming 500 years. The $\mathrm{CO}_{2}$ concentration in the atmosphere at the time was around $280 \mathrm{ppm}$. By 1985 the issue was being studied around the world and a joint UNEP/WMO/ICSU Conference concluded that "as a result of the increasing greenhouse gases it is not believed that in the first half of the next century ( $21^{\text {st }}$ century) a rise of global mean temperature could occur which is

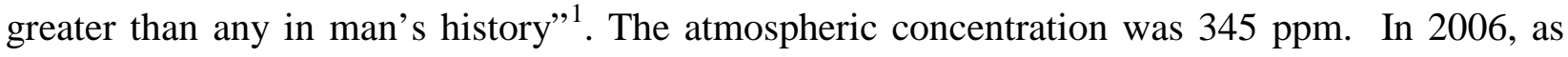
atmospheric $\mathrm{CO}_{2}$ concentration was racing inevitably toward 400ppm, former Vice President $\mathrm{Al}$ Gore's documentary, An Inconvenient Truth ${ }^{2}$, made the issue readily accessible to people around the world. Peak Oil refers to the point in time at which the world production rate ceases to grow, and begins an irreversible decline. In 1900 world oil produciton was less than 1 million barrels per day (mbd), but grew at an annual rate of about $4 \%$ for most of the century to nearly 75 mbd today. Most reliable sources indicate that oil production has ceased to grow since 2005, and the price has trippled over the decade 1999-2009. This issue first started to be discussed by nonspecialists after prominent petroleum geologist Colin Campbell (Campbell and Laherrere, 1998) published an article in Scientific American. Campbell's analysis indicates that the available oil supply in just 40 years could be less than half of today. The prospect of oil supply declining while demand continues to increase has serious economic implications. Since the 2004 release of a DVD on peak oil aimed at a general audience, The End of Suburbia ${ }^{3}$, a large number of websites, videos, books and blogs have emerged and the issue has developed a dedicated following. For

\footnotetext{
${ }^{1}$ World Meteorological Organization, www.wmo.int

${ }^{2}$ Guggenheim, D. (Director). (2006). [DVD]. Hollywood: Paramount

${ }^{3}$ Greene, G., Silverthorn, B., Zwicker, B. (2004). [DVD]. Toronto: Electric Wallpaper Co.
} 
example, the website The Oil Drum ${ }^{4}$ started in 2005, has more than 26,000 RSS feed subscriptions and provides a broad and current coverage of the global oil production industry and government policies.

Many communities worldwide, most notably the Transition Towns ${ }^{5}$ movement are seeking local actions that address the risks of oil supply decline and climate change. These local initiatives have a common perception of lack of leadership in government and lack of social responsibility in business. Participants perceive that the problem of Peak Oil could undermine their food supply systems in particular. National policy and research incentives are not currently targeting adaptability and resilience measures that would be relevant to local communities. For example, biofuel targets enacted in New Zealand 2006 clearly did not help a town such as Oamaru deal with high fuel prices in 2009. Rather, people feel that local solutions must be developed which allow participation in activities and movement of goods from production to markets with lower fuel consumption. These resilient structures will have more to do with land use and cooperation than with substitution of fuels or new vehicle technology that are beyond the control of local communities.

\section{Transition Engineering for Local Community Action}

A local community will be defined operationally as a group of stakeholders forming an organisational structure with the aim of meeting the needs of its members. A local socioeconomic structure will be defined organisationally as a system including the governance and regulatory bodies, the built environment and infrastructure, personal residences, appliances and vehicles, and the commercial, agricultural, and industrial assets in the local area. Twentieth Century community organisational structures are indicative of abundant energy availability and global supply chains. One of the precepts of Transition Engineering is that adaptation of existing socio-economic structures to reduced energy availability necessitates the creation and

\footnotetext{
${ }^{4}$ www.theoildrum.com

${ }^{5}$ http://www.transitiontowns.org and http://transitionculture.org
} 
maintenance of strong local connections in order to meet basic needs for wellbeing and to foster the liberty to pursue a desired quality of life.

The transition engineering project requires changes in the organisational structure of the current community system. This requires transformation of the members' cognitive structures, regarding the destabilising consequences of the current growth paradigm, and new ideas must feed forward into future planning decisions. This mental adaptation to a changed virtual landscape (e.g. constrained oil future vs. 'business as usual') is used to identify barriers as well as opportunities for 'real-world' adaptation actions. Appropriate action can then be taken. We propose that helping people make this mental adaptation is part of the larger project of transition engineering.

We have developed a method which we call TransitionScape (Dale et al, 2008) as a way to move communities from a point of concern about the future into positive action focused on adaptive change. As engineers, we cannot work on a vague notion of 'sustainable development' without specific project specifications. In order for these communities to generate and undertake projects meaningful to the objectives of sustainable development, the members must organise themselves such that they agree on the projects that need developing. The research group is comprised of Mechanical Engineers, and according to our professional methods, we have developed a set of project requirements for the TransitionScape methodology:

Requirements for Community-Initiated Change Projects

- Recognition, by the community members, of the situation being faced

- Awareness of how this environment is functionally different to that for which many of the current community systems are suited

- Facilitation of creativity of adaptation responses to the challenges of the new environment

- Increased connectivity and organisational structures appropriate to these challenges

- Acquisition of skills relevant to the new landscape

- Fostering of problem solving and cooperation skills among the community members. 
The next section is a review of the literature on the field of psychological adaptation and sustainability planning used to design the TransitionScape method. Section 3 describes the method. Section 4 gives the background for the case study and section 5 explains the design of the workshop and the tools used. Section 6 gives the results and responses. Section 7 presents an assessment of the workshop and the method according to Tippet's criteria for sustainable development, and section 8 gives the concluding remarks.

\section{REVIEW OF LITERATURE}

The project generation process was designed using information from the literature about how thinking and actions change due to external disturbance or trauma. The hypothesis was that Peak Oil and Climate Change represent sufficiently traumatic disturbance to the individual perception of the safety, security and sustainability of their current life-supporting systems. Tedeschi and Calhoun's (1995) Functional-Descriptive Model offers a theory of post-trauma psychological adaptation that describes the stages of development of an individual after a traumatic event such as bereavement or an accident.

1. Seismic challenge to pre-trauma belief schema (paradigm)

2. Ruminative activity occurring at both an automatic and deliberate level Automatic:

3. Disengagement from unreachable goals in the post-trauma environment

4. Adoption of new coping behaviours

5. Construction of post-trauma belief schema (paradigm)

Deliberate

6. Narrative development such as a search for meaning

This model can be schematically represented by appealing to Gunderson and Holling's (2002) ecological metaphor of the Adaptive Cycle as shown in Figure 1. As a system exploits 
available resources it passes through a growth phase ( $\mathbf{r}$ to $\mathbf{K}$ ) [formation of belief schema] of increasing organisational structure and rigidity. The system expends ever increasing amounts of resources on maintaining internal structure in order to maintain its development trajectory [conservation]. This structure will be subject to various perturbations from continual environmental change, placing stress on the system, until such time as the system experiences 'collapse' ( $\mathbf{K}$ to $\mathbf{\Omega}$ ) [seismic challenge to schema] and resources are released back to the environment [disengagement from goals]. A period of re-organisation ( $\boldsymbol{\alpha}$ ) occurs [adoption of new coping behaviours] until structures suitable to the new environment form and resources are exploited toward system growth (r) [construction of post-trauma schema].

Figure 1 here 
FIGURE 1 Adaptive cycle of mental processes [6]

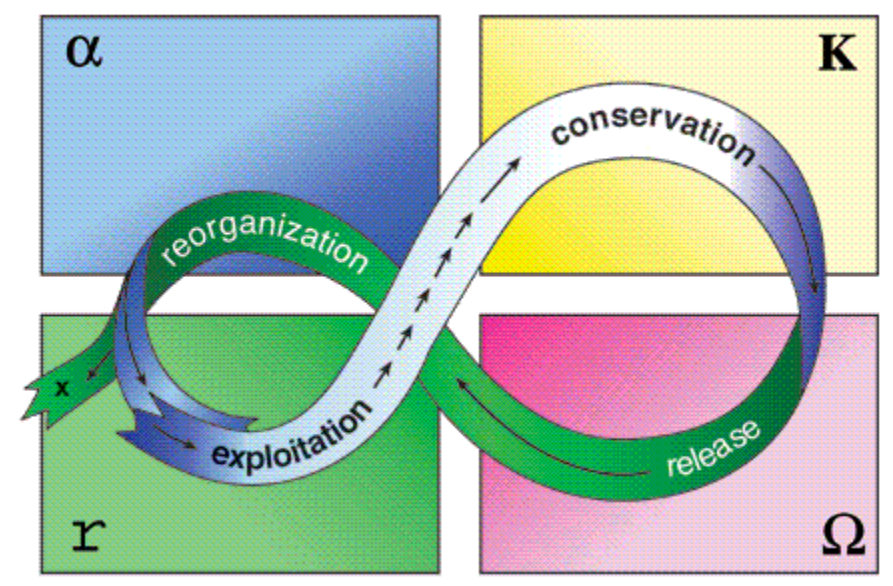


The adaptive cycle occurs at each level of organisation (holon) to form nested, interacting loops. At one level the adaptive cycle of the mental processes of the individual may be manipulated through the use of imaginative tools to experience a virtual 'collapse' process and to vision subsequent adaptive behaviour. The conceptual re-organisation experienced by the individual may then feed forward into future decision making about the community system of which they are a part thus influencing the path of the adaptive cycle followed by the community as shown in Figure 2. It is assumed that reduction of the 'collapse' portion of the cycle is desirable.

Figure 2 here 
FIGURE 2 Adaptive cycles of the individual and community

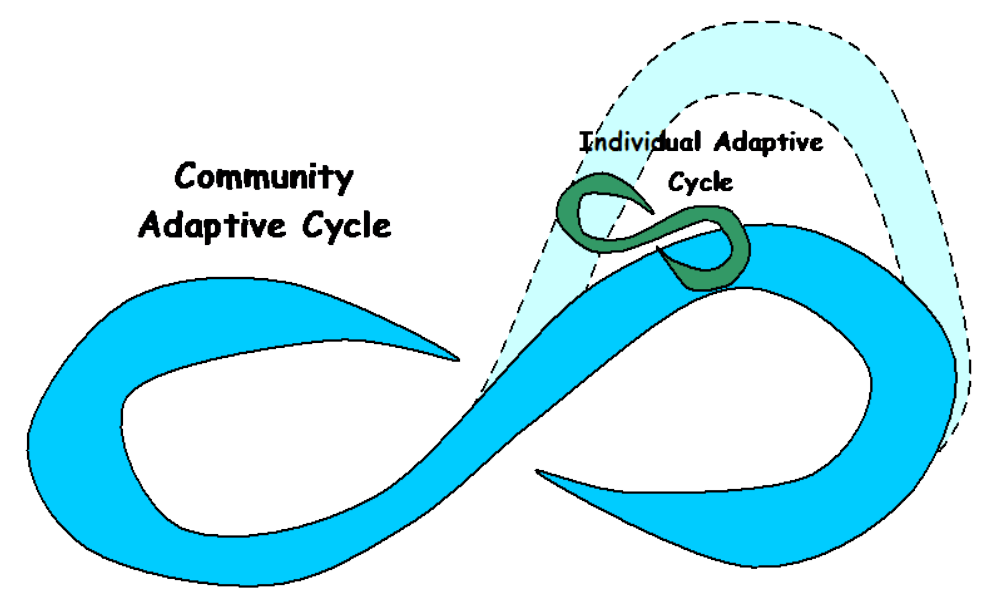


Planning processes using scenario planning are defined as “a process of positing several informed, plausible and imagined alternative future environments in which decisions about the future may be played out, for the purpose of changing current thinking. Scenario planning is reported as improving decision making, enhancing human and organization learning and improving performance” (Chermack and Lynham, 2002). Scenario planning processes may make use of this interaction between individuals and the wider systems of which they form a part. Within the community development literature (James and Lahti 2004), (Roseland 1998) there is an awareness that priority should be given to those projects that can be undertaken easily and provide the greatest benefit for the least investment - picking the 'low hanging fruit'. A number of both ecological and participatory planning processes have been reported. Tippets (2007) offers one of the only set of criteria by which to assess the success of these methodologies against the objectives of generating projects that manage the risks of un-sustainability. Tippet defines five challenges for planning processes and expounds a set of criteria for assessing the merits of the particular interventions in addressing each challenge:

\section{Engage meaningful participation with community members and other stakeholders}

Active engagement in developing plans/options

Hands on process and dialogue

Use of visual and presentational knowledge

Use of creative thinking tools

Close attention to decision making process

\section{Develop beneficial synergies across levels of scale by}

Principles that can be transferred across scales

Uses transferable tools and materials

Provides meta-data structure for planning

Process linking multiple geographical scales 


\section{Produce plans with integrated and sustainable outcomes}

Explicit focus on sustainability

Use sustainability criteria in decision making

Focus on social capital

Focus on environmental integrity

Focus on economic vitality

Brings together different perspectives and views

Takes holistic approach

\section{Go beyond 'end-of-pipe’ to eco-systemic solutions}

Involves spatial design and analysis

Tools to apply ecological design principles

Looks at ecological and human interaction

Focus on underlying processes and patterns

Structured design process

Design on a life cycle basis

\section{Develop capacity in stakeholders and practitioners to meet the above challenges}

Skills development explicit in process

Content education incorporated into process

Incorporates use of 'multiple intelligences'

Attention to process and programme development

The literature review revealed that all previous studies were focused on immediate and tangible issues like a polluted industrial site where the remedial actions were rather well understood. The previously developed methods used community engagement that was focused on making decisions about ways to address this one problem. There were no reported processes developed to help communities deal with the much more nebulous issues of Peak Oil and Climate 
Change. The TransitionScape methodology was designed with these challenges outlined by Tippets as guidelines for developing materials and organising activities. The methodology was also assessed against Tippet's criteria based on observations made during application of the methodology in the small city of Oamaru, New Zealand.

\section{METHOD DEVELOPMENT}

The aim of this action research project was to develop a methodology that could bring the capabilities of engineering into the processes of helping local communities deal with the global issues of Peak Oil and Climate Change. The TransitionScape methodology is designed for a workshop or seminar setting to be led by a Transition Engineering supervisor and facilitated by assistants. The workshop is set out as a series of presentations and interactive sessions. Some key tasks in the method were aimed at initiating the transformation of the current community systems from organisational structures well suited to an energy-rich environment into more resilient systems, able to adapt to the challenges of lower energy availability:

- Raise awareness of upcoming socio-economic and environmental challenges facing the community and the ramifications of these challenges

- Map out the landscape to which they must adapt

- Facilitate creative thinking within the system directed toward adaptation to this new environment

- Engender a sense of belief that the necessary changes can be made

- Facilitate formation of the new organisational structures

- Focus thinking from general esoteric matters onto specific tasks and projects

- Enable learning of problem-solving skills necessary for completion of the specified tasks

- Foster a sense within the township of support from the wider community

- Enable a recognition of the wealth of local resources 
- Generate an understanding of the structures that need changing in response to the upcoming challenges

- Raise awareness of current activities within the town or wider community being undertaken directed towards the same ends

A conventional lecture format was selected as the most suitable format for the delivery of the large amount of information required to raise awareness of the specific facts concerning the future adaptation environment such as Climate Change and Peak Oil. These lectures include analysis of the future availability of energy resources including the inability of renewable energy sources to meet the shortfall in demand capacity in light of decreasing fossil fuel supplies. The information needs to be delivered in such a way as to ensure that all participants are conversant, or up to speed, with the current situation, coupled with a description of best estimate projections of environmental disruption due to a changing climate. This further ensures an understanding amongst participants that, even disregarding resource constraints, there are other compelling reasons for behaviour change.

The lecture content also aimed to incorporate a sense of empowerment, a sense that the transition task can be achieved, and that support is present from a wider network of willing allies. This was achieved via the use of metaphor utilising a well-known mythology (which we termed pop-mythology as opposed to classical mythology) as an analogy for the community's current situation. As with all cultural moral stories (e.g. The Emperor's New Clothes, The Tortoise and the Hare), the narrative expresses the basic situation and solution of a complex problem in a way that captures the essence rather than specific facts. These types of shared stories form cultural ties that contribute to group identity and a sense of belonging among the members. Further support and encouragement is provided by generating awareness that the current and upcoming challenges, whilst seeming unmanageable are part of a wider process of change and growth/development with reference to psychological theory and precedents. 


\section{Scenarios - moving the mindset}

A series of 'collapse' setting stories, or scenarios, relating to disruption and decline of vital infrastructures (oil and electricity supply, environmental and social degradation) were developed to further establish consciousness within the participants of the imminent adaptation environment. The stories were designed to really bring home the effects of upcoming challenges and to ground these challenges in the context of the participants' everyday experience. The objective of the stories was to challenge thinking about abstract and frightening problems, to break through the barriers of fear of the unknown, and to facilitate creative adaptation. The participants are guided through these virtual landscapes and invited to envision the necessary structural re-organisation. Following Tippets (2007) the scenario story approach maximizes creativity and variety of suggestions ('blue sky thinking') and focuses thinking. Also, in order to manage the dominant personality issue in discussion and workshop forums, the participants' responses are made and kept individually on coloured cards (one colour for each scenario).

\section{Responses organised via dimension and scale - Transition Space}

At the end of the four scenarios participants share their responses, again, in a way that cannot be dominated by strong personalities. Participants are invited to place their responses to the scenarios into the place where they feel it is most appropriate within a three dimensional space (the 'transition space'). The three-dimension space comprises the three dimensions of People, Place and Time. The People dimension ranges in scale from the individual level up to the international community. The Place dimension ranges in scale from backyard to the level of the whole planet. The Time dimension ranges from the present to the distant future. These are representative of the social, land-scale and time-scale dimensions of the various adaptation projects.

The purpose of the exercise is twofold: firstly, to generate in participants an appreciation of the effects of scale and dimension on the specific project they have conceptualized. For instance a 
realisation that some actions may only be carried out at a certain level within the threedimensional space, such as 'plant vegetable garden', whereas others are implemented at one scale yet have effects across a wide range of scales and dimensions, such as 'national regulations allowing local farmer's markets'. The exercise can also uncover means by which the project may be undertaken, for instance placing the project within the appropriate scale and dimension may enable a recognition that the support of others is necessary for the realisation of certain tasks and a reflection on the existence (or not) of structures currently obstructing the realisation of that project.

The second purpose of the exercise is to generate participation and interaction of the participants focusing on specific tasks. As the participants gather to carry out the exercise, discussion and evaluation of ideas and network communication occurs naturally and spontaneously. In this manner many controversial or unconventional ideas, sometimes suppressed in open discussion, World Café, or brainstorming workshops may be brought out allowing full creativity to flourish. The structured format also enables a greater generation of ideas in a short space of time than open discussion would allow.

\section{Support and Empowerment}

Awareness of current activities of other local communities engenders hope within participants and a sense that the transition undertaking is a genuine possibility, and that future work will not be taken in isolation. This fortifies participants' resolve and strengthens connections to a wider community. This also gives a context for the efforts the participants will undertake as well as supplying a source of future support and guidance.

\section{Assessing the Current Situation - Resource mapping}

In keeping with Tippets (2007) an effort is made to increase participants' appreciation of the positive attributes and assets within their community. This is achieved by asking participants to 
identify natural resources and assets within the region. Participants are asked to write down positive aspects of their current community - things that they feel must be retained and protected for the community, whatever other changes may occur in the future. Then participants are asked to list three existing critical infrastructural assets. Again to maximise variety of responses and increase participation, individuals are not asked to tell the group their suggestions, but rather all responses are recorded on different coloured cards, one for each of the natural assets, positive community assets, negative aspects and critical infrastructure. These are then collected and collated into a resource 'map' by the assistants.

In order to raise awareness of possible barriers to transition projects, participants are guided through the virtual landscape of another scenario wherein all adaptation measures have been carried out successfully and transition to a post-carbon society has been as smooth as possible. Participants are asked to identify any existing barriers to these actions being undertaken at present. Again to maximise variety of responses they are written down individually.

\section{Visioning Alternative Options - Transition Space (a reprise)}

The adaptation responses to the 'collapse' scenarios are collated and classified under various topics depending on the themes or recurring patterns occurring within the content. It is fully accepted that this process, undertaken by the action researcher, is liable to be influenced by the biases of the researcher. However, the topics discovered are 'grounded' in the participants' responses. These topics are then laid out with their various associated projects in an appropriate position within the now transformed 'transition space', two of the dimensions, time and space, are mapped out within the venue using the floor area, the participants themselves now representing the social dimension.

Participants start outside the space and are then invited to enter and move within the space until they find a topic and associated projects with which they feel their interests and abilities are most resonant. When they have decided on a topic and arrived in that space, they introduce 
themselves to other participants who have also chosen to work on the same topic. The process of participants starting outside the 'transition space' and then stepping over the threshold symbolically reinforces the sense that this is a different paradigm into which the participants are moving and that they are choosing to do so with deliberate and wilful purpose, thus strengthening resolution and commitment to the transition intention. Within the space participants meet likeminded members of their community, some of whom may have been unknown to them before the event. This increases the overall network connectivity of the community but particularly focuses the creation of organisational links enabling resilience and adaptation to the challenges of the future.

Participants are asked to tell the other people in their "space" about their interests in the projects listed, and what skills and resources they could bring to the projects. The participants are then asked to choose one project for the group in each space and work through a planning exercise detailing ways and means by which the project could be undertaken. Before the project planning work commences, the session convenor provides a mini-lecture with instruction on how to plan a project and guides to follow for project planning are distributed. Feedback on the event may be taken by means of anonymous forms and/or by interviews both at the event and afterward.

\section{Case Study Setting}

TransitionScape was trialled at a weekend forum organised by the Natural Heritage Society Oamaru on the $15^{\text {th }}$ and $16^{\text {th }}$ March 2008 . Oamaru is situated around $15 \mathrm{~km}$ south of the mouth of the Waitaki River on New Zealand's South Island in North Otago. Oamaru was first settled by Europeans in the 1850s and quickly thrived due to the agricultural land between the Kakanui Mountains and Waitaki River and access to a port. The town soon became a major trade center, acting as both a commercial port and fishing harbour. The presence of abundant local limestone 
has ensured a great number of stone built buildings within the town and the existence of a historic precinct near the harbour shown in Figure 3. The town of Oamaru saw significant population decline when local mining played out and the port fell into disuse. The population has been holding steady around 12,000 for the past decade.

The Oamaru Natural Heritage Society is a local organization set up to promote and support the preservation of the historical architecture of Oamaru and to embrace sustainable initiatives in North Otago. ${ }^{6}$ The society has a particular focus on:

- Organic farming and appropriate technology

- Produce market and cottage industry

- Preservation and conservation of natural and cultural resources

- Environmental and socially sustainable employment

- Education based training programmes

The society holds an annual forum to discuss matters of interest. In 2007 speakers included Dr Susan Krumdieck and David Holmgren. The 2008 forum organised for Saturday $15^{\text {th }}$ and Sunday $16^{\text {th }}$ March was titled Climate Disruption - Transition Towns - One Response.

Figure 3 here

${ }^{6}$ http://www.oamaru.co.nz/nhs/index.htm 
FIGURE 3 The historic district of the town of Oamaru, New Zealand

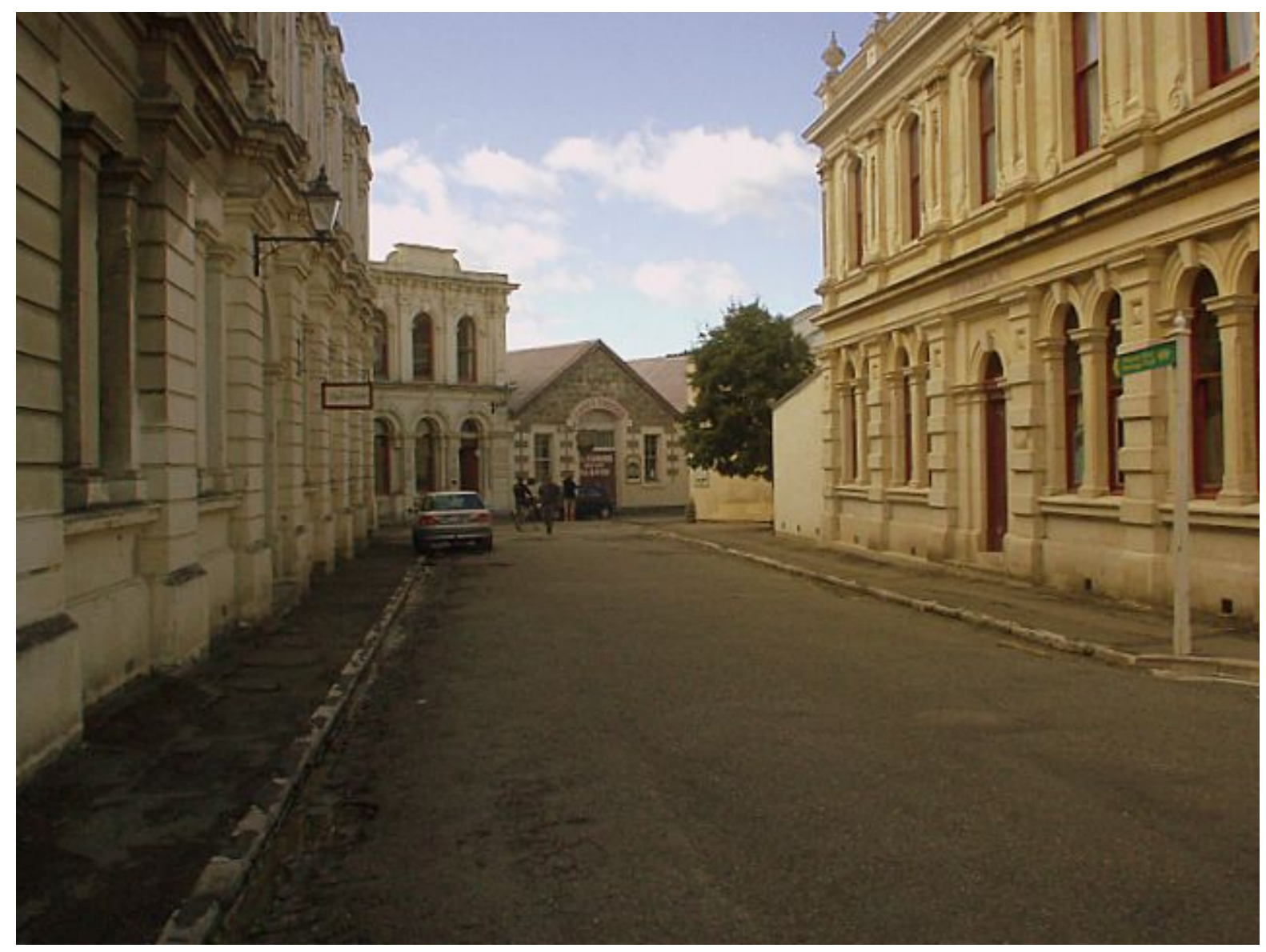


Some of the organizers of the Oamaru workshop event had participated in events in a neighboring town of Hampden-Moeraki. A group of people in Hampden, organised as the Hampden Energy Committee, had asked Dr. Krumdieck and other speakers on several occasions to give presentations in their community hall about Peak Oil, Climate Change and energy security. The group organized several years prior to the start of the Transition Towns movement and did not re-brand as a Transition Town. The Hampden-Moeraki group has remained active since 2005 with projects including setting up a community library, organising political debates and dinners, and bringing in volunteer music groups from the larger cities. They have also worked to stop development they saw as environmentally destructive through the New Zealand Environment Court system. The main leader of the Hampden group is an engineer and he tends to approach the local community actions as projects to be planned and achieved. The research group's prior experience with the Hampden group was partly responsible for the idea to apply engineering principles and processes to the area of local community action.

\section{IMPLEMENTATION IN AN ACTION RESEARCH WORKSHOP}

This section describes the TransitionScape workshop designed for the Oamaru Natural Heritage Society event (see Appendix A - Forum Timetable). The workshop was scheduled to run all day Saturday and until lunch time on Sunday. The workshop activities were arranged into four sessions, three on the first day, research team organization of responses and transition space in the evening, and then the fourth session on the second day. The general framework is described below. Detailed descriptions of the activities in the sessions and the props developed for the workshop are then presented in sub-sections.

\section{Session 1 - Problem Identification:}

This session was delivered in a conventional lecture format with content including an analysis of future fossil fuel availability, renewable energy inability to cover 'shortfall' in oil production, and environmental risks of changing climate. The case study participants had seminars and video 
screening about the subjects of Peak Oil and Climate Change throughout the previous year. The lecture in this setting was a review and recognition of the issues and recognition of the participant's concern. The gravity of the issues was recognized and the difficulty and emotional stress of thinking about the implications were recognised. The pop-mythology was presented in order to bring an emotional and shared understanding of the nature of the challenge. In this session, the emotional response was also explored.

\section{Session 2 - Scenarios:}

The scenarios or forward-looking stories are created to help participants face their worst fears and stimulate their natural problem solving instincts. Four virtual landscapes were generated through scenario stories dealing with (1) disruption to the oil supply, (2) irregular but frequent electrical grid failure, (3) environmental degradation and (4) social dilapidation in order to enable participants to generate their own adaptation responses to these situations. The scenario stories were written by Dr. Krumdieck using the first person, with the intention of mentally placing the participants in the situation.

\section{Session 3 - Asset Mapping:}

Participants were asked to make note of natural resources within the region; features of the local community that they felt should be kept 'at all costs'; negative features that effort should be made to change and to list three critical infrastructural assets. Participants were also asked to recognize skills that both exist and those that would be needed for the transition project within the region and to identify any existing barriers to the transition project. The responses to the scenarios, the assets and the barriers were organised by the TransitionScape team after the workshop sessions ended for the day. Assets were collated into a resource 'map' of the community and put into a PowerPoint presentation for reflection back to participants at the next session. 


\section{Session 4 - Planning Solutions:}

The final session started with feedback the community responses according to natural groupings found upon thematic analysis of the responses:
1. Demand Management
2. Infrastructure and Technology
3. Knowledge, Skills and Education
4. Local Produce and Markets
5. Community Networks
6. Re-localising Economy
7. Governance and Regulation
8. Restoration and Reclamation

These topics were felt to be both trans-disciplinary and interconnected as well as transcending conventional community organisational structures. For these reasons some projects fell under two (or more) headings for planning. It was hoped that members from the different planning groups represented by these headings would co-operate with members of another planning group (or groups) on various projects thus strengthening an integrated planning approach. The Transition Space exercise was carried out and the project planning training activity was initiated.

\section{Action Research Method Preparation}

As discussed previously the TransitionScape methodology was trialled at the "Transition - One Response” weekend forum hosted by the Natural Heritage Society Oamaru on Saturday $15^{\text {th }}$ and Sunday $16^{\text {th }}$ March 2008. Five members of the Advanced Energy and Materials Systems research group were in attendance: Associate Prof. Susan Krumdieck (Group Head), Dr. Shannon Page (Researcher), Dr. Kerry Mulligan (Researcher), Stacy Rendall (PhD Candidate) and Michael Dale (PhD Candidate). The event was held at the Penguin Club, Oamaru, a venue capable of accommodating approximately sixty participants comfortably. The schedule of the forum was 
split into five sessions over the two days by the organisers (see Appendix A - Forum Timetable:) with all but one of the sessions, the reports from the Hampden group, to be facilitated by the action research team.

This placed immediate constraints of both time and organisation upon the process. Our approach was to organise the sessions around the steps of problems solving: (1) problem identification, (2) current situation, (3) visioning solutions and (4) planning solutions (see Appendix B - Session Plan:). This would allow us to best coordinate the exercises we had planned with the structure of the event and the content of the speakers of the Hampden Energy Group whose lecture would form part of the ‘current situation’ step.

The location of the workshop was four hours drive from University of Canterbury, so it was important that all of the necessary materials were resourced and brought by the team to the venue: Laptops for lecture presentation and data analysis - all other presentation apparatus was supplied by the organisers,

Pens (enough for sixty plus participants), Coloured card and sticky notes (8 different colours and enough for all of the responses of sixty plus participants),

Representation of the three dimensional 'transition space' posters and frames to hold them so people could walk around them.

Paper for topic headings and projects, Worksheets, Feedback forms,

Documentation equipment - video recorder and digital camera, Masking tape, Blue tack.

For the three dimensional space onto which the 'collapse' scenario responses would be placed it was decided that a freestanding structure would offer the best participatory interaction possible. This was achieved by arranging three posters (one for each dimension) on display boards to form a triangular stand (see Appendix C - Poster Design:), the participants could then stick the pieces of card with their responses onto the posters. 


\section{The Workshop Forum}

\section{Problems of Peak Oil and Climate Change}

For the first day the venue was arranged in conventional lecture theatre style with rows of seating facing the presentation equipment and speakers. Prof. Krumdieck delivered the lecture of the first session, entitled "Setting the Scene". Attention was paid to the challenges of Peak Oil and Climate Change with particular emphasis on 1950's consumption levels as a comparative benchmark. The idea was presented that the paradigm of economic growth without social or environmental responsibility produces a "boom and bust" pattern to development. While the "boom and bust" pattern may enrich a few, it always exhausts valuable resources and degrades the wellbeing of future societies. The main focus of the problem identification was of the dominant paradigm of undirected and unquestioned economic growth. There is evidence in the literature to support the view that "growth cannot be sustainable indefinitely on a finite planet" (Constanza and Daly, 1992).

\section{$\underline{\text { Pop-Mythology }}$}

The researchers reviewed numerous historical cultural myths to find a good fit with the dilemmas posed by Peak Oil and Climate Change. The Monkey Trap and The Tragedy of the Commons were seen as possible pop-mythologies, but it is possible that people before the industrial revolution have not faced situations like climate change. A modern 'pop mythology' was developed, based on the Lord of the Rings movie trilogy directed by Peter Jackson and filmed in New Zealand. ${ }^{7}$ The movies are based on a well-known fantasy trilogy by J.R.R. Tolkien, and portray the struggle of a fellowship of a few brave, and some basically powerless individuals to overcome a great but corrupting power. This corrupt power reflects the same issues as the paradigm of uncontrolled consumption growth and unrelenting exploitation of fossil fuels. The pop-mythology further explained how powerful leaders, warriors and wizards might hold off the

\footnotetext{
${ }^{7}$ The Fellowship of the Ring (2001), The Two Towers (2002), The Return of the King (2003), Wellington: New Line Productions, Inc.
} 
destruction for a while, but the struggle of the local, rather powerless people is needed to make a paradigm shift. Hope is possible if ordinary people can help each other and make the decision to seek sustained value rather than un-restrained consumption growth. Fossil fuels do indeed provide unprecedented power, but the ultimate price over time is paid in degradation of human value (as in the transformation of Gollum). The difficulty that the main character has in not being able to let go of the ring is also symbolic of the conflict we have with ourselves as we try to reduce our use of the most convenient and low cost energy source ever developed. The popmythology of the Lord of the Rings movie trilogy was used to provide reflection and internalization of the problems of Peak Oil and Climate Change. (See Appendix D - PopMythology PowerPoint Presentation).

\section{Emotional Response}

Comparison was made between our perspective of the current situation and the Kübler-Ross (1973) model of the Stages of Grief experienced by the terminally ill or recently bereaved. Focus was placed on the need to move through the entire process in order to reach a point where positive action is possible. Explanation of the stages also helped participants to understand that other people in their community who they may perceive as being uninformed, uninterested or hostile, may actually be at one of the earlier stages in the acceptance process (see Appendix E Stages of Grief for Energy and Environmental Issues). The PowerPoint slides had been used in several previous presentations by Dr. Krumdieck and were known to be effective at helping people manage their own response, their frustration with others, and to then move toward action.

\section{Scenarios}

The second session comprised the 'collapse' scenarios. Four virtual landscapes were generated (see Appendix F - Adaptation Scenarios) dealing with disruption to the oil supply, irregular and frequent electrical grid failure, environmental degradation and social dilapidation. Dr. Krumdieck read out each of the scenario stories without visual aides. The scenarios were designed to engage 
the participants and to mentally perturb them into a consideration of the adaptations they would make to the collapse situations described. The workshop assistants distributed coloured sticky notes and pens. After each story was read participants were instructed to write down their coping and adaptation behaviours in response to these situations.

At the end of the session participants were invited to step outside to place their responses within the three-dimensional 'transition space'. The structure was placed to allow $360^{\circ}$ access with space for participants to gather and discuss observations as shown in Figure 4 (see Appendix C-Poster design).

Figure 4 here 
FIGURE 4 Participants place responses into the social, spatial and temporal context.
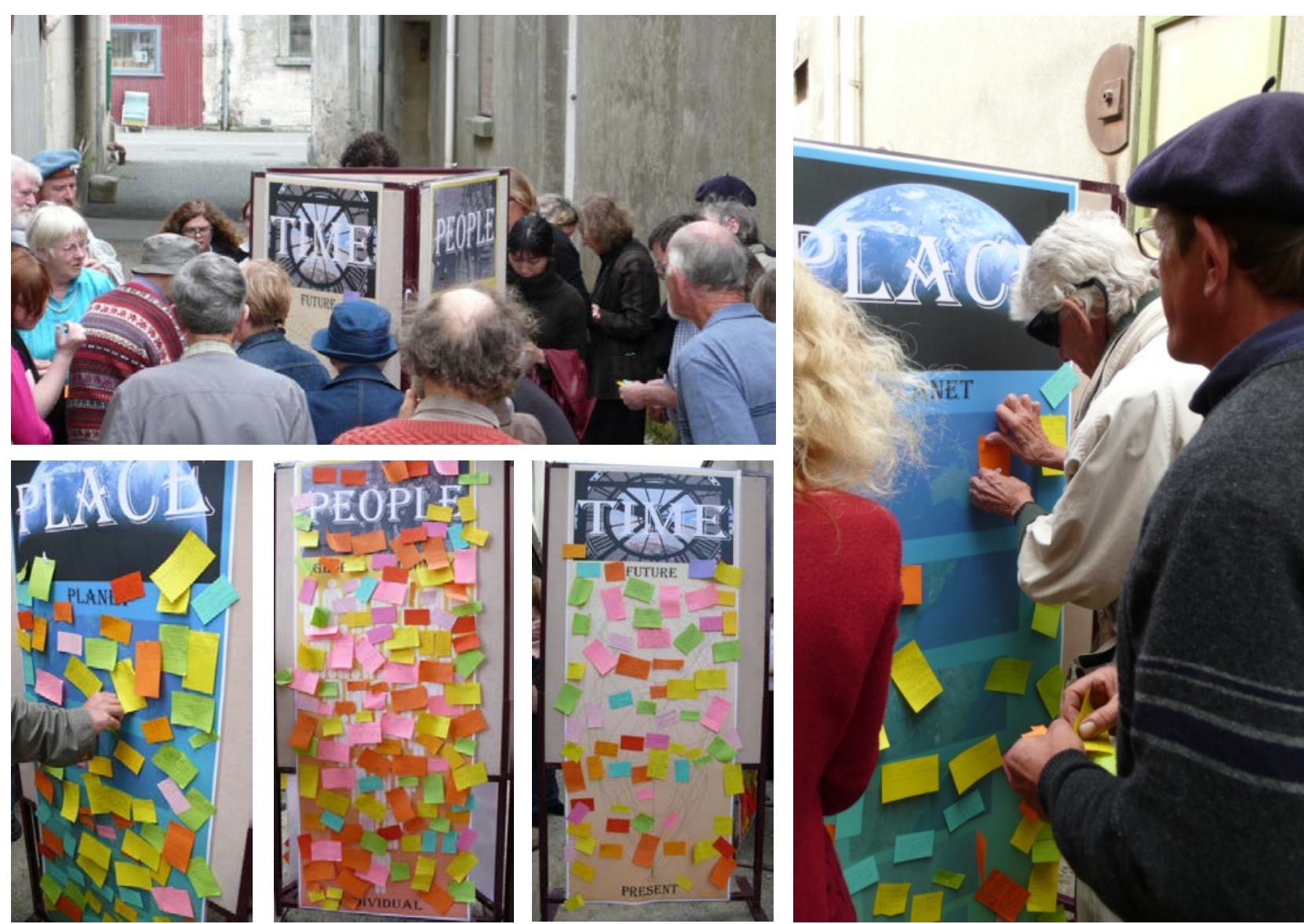


\section{Assessing the Current Situation \& Resource Mapping}

Members of the Hampden Energy Group spoke during the third session on a variety of topics including community networks and information systems, solid waste management, public transport and distributed electricity generation. They explained how their group had started, activities they had carried out, difficulties they had faced, and finally they described some of their successful projects. These presentations were intended to provide the Oamaru participants with examples of successful local community projects, and to encourage them to pursue projects that they cared about.

The fourth session was given over to asset recognition and identifying barriers to projects. Participants were asked to make note of natural resources within the region, and features of the local community that they felt should be kept 'at all costs'. They were asked to list three critical infrastructural assets. Participants were also asked to identify negative features that effort should be made to change. These nominated assets were then collated into a resource 'map' of Oamaru (see next section). Participants were then taken through the fifth scenario (see Appendix E Transition Scenario) in order to identify current barriers to transition projects being carried out.

\section{Visioning and Planning of Local Transition Projects}

After the first day's activities the members of the research group collated the responses to the 'collapse' scenarios according to the various topics using a thematic analysis. These themes were found to be:

- Demand Management

- Restoration and Reclamation

- Knowledge, Skills and Education

- Community Networks

- Infrastructure and Technology

- Local Production and Markets 
- Re-localising Economy

- Governance and Regulation

These topics were felt to be both trans-disciplinary and interconnected as well as transcending conventional community organisational structures. The topics were then written onto A4 sheets (one per heading).

Prior to the second day's proceedings the venue was rearranged such that the seating was placed around the sides and back of the room leaving an open space within the middle. This 'transition space' was marked out on the floor using masking tape. The day started with a brief explanation of the work that had been done collating the participants' responses and the method of the session. The topics were then laid out in the space, after a brief description of each, and the participants were invited to step into the 'transition space', choose a topic and meet others who had chosen the same. All of the participants went to a place in the transition space. None of the projects had fewer than five participants.

Participants were then asked to discuss possible projects within the groups they had formed under their various topics and work through the exercises on the worksheets provided. The worksheets prompted participants to think through the normal process of project planning and project management (see Appendix $H$ - Project Planning Exercise). At the end of the day's activities feedback forms (see Appendix I - Feedback Questions) were handed out to obtain participants' reactions to the TransitionScape methodology.

\section{Findings and Data Analysis}

\section{Responses to "Collapse Scenarios"}

The research team collected the written responses to the scenarios presented. Each scenario was read out in the form of a story about what life is like in a place that is experiencing the problems associated with: (1) disruption to the oil supply, (2) irregular but frequent electrical grid failure, 
(3) environmental degradation and (4) social dilapidation. In response to the 'collapse' scenarios the proposed projects were organised into categories for project planning. The most common themes are given in Table 1 and all of the responses received are given in Appendix F Adaptation Scenarios.

\section{Participant Responses to Collapse Scenarios.}

Many of the projects could easily be carried out by community members allowing recognition and utilisation of the current skills base within the community. Most of the projects logically addressed the explicit aims but also had multiple benefits and purposes within the transition process. Several of the adaptation responses required no more than the establishment of information networks or cooperative arrangements within the community. For example, in response to the peak oil scenario, several participants proposed ride-sharing networks for communal/community shopping trips to the larger city of Dunedin which is one hour distant from Oamaru. One, but by no means the only, method by which to achieve this end would be the construction of an on-line database or webpage designed specifically for these purposes. The ride share network would reduce demand on transport services whilst simultaneously creating and strengthening organisational structures aligned with increasing sustainable and community value as well as enabling community members to feel empowered. All of these benefits would serve as a solid platform from which to increase the likelihood of success of future projects. Local production of bio-fuels, especially utilising waste resources such as used vegetable oil, was another project proposed by several participants. Biodiesel production could possibly be undertaken using the skills base and resources within the community, but would likely require learning and specialization by some people. Initial action would probably take the form of a feasibility study, investigating, amongst other things, resource availability and cost, the possible market or essential uses for bio-fuel and capital and running costs. 
Table 1 Summary of 'Collapse' Scenario Responses from Session 2

\begin{tabular}{ll}
\hline Demand Management & Infrastructure and Technology \\
\hline Transport mode change - bike, walk, etc. & Build up rail network \\
$\begin{array}{l}\text { Ride sharing } \\
\text { Cars only for essential trips } \\
\text { Work from home }\end{array}$ & Prospect for more oil \\
\hline Local Produce and Markets & Governance and Regulation \\
\hline Market gardens & Work from home \\
Farmers market & Prioritise/Restrict fuel use \\
Community garden & Use local resources locally \\
Home grown food & Don't export local resources \\
Use local resources locally & \\
Don't export local resources & \\
\hline Community Networks & Re-localising Economy \\
\hline Ride sharing & Work from home \\
Shared use of community resources & Use local resources locally \\
Communal shopping & Don’t export local resources \\
Community gardens & \\
\hline Knowledge, Skills and Education & Restoration and Reclamation \\
\hline Conservation education: Transport & No projects \\
\hline
\end{tabular}


Further projects may require acceptance and assistance from the wider community. Facilitating change to lower energy transport modes, e.g. walking or cycling, or enabling people to work from home might necessitate research into community members' transport choices and then action based upon findings. Infrastructural changes, such as introduction of cycle lanes or cycle-only streets, would need cooperation of the town council. Governance to protect and prioritise local use of local resources may be possible but would require extensive research into the complex, interacting mechanisms of many interconnected systems; legislative, economic, social, etc. Action on "building up the rail network" would require collective initiative on a regional and national level, although lobbying could begin at the local level. Research into the feasibility of introducing local rail services has already been carried out by the Hampden Energy Community Action Group.

\section{Results of the asset mapping exercise}

Results of the Asset Mapping exercise are summarised in Table 2 with full response set given in Appendix G. Within the asset identification segment of the forum "low population density" was identified as a positive asset whilst both the "unused railway station”, the rail line being "not well utilised" and the "high road accident rates" were noted as aspects of the community in need of change. Further the "road and rail networks" and "long-service buses" were recognised as critical infrastructural assets. Within the skills identification portion of the forum many capabilities directly related to the achievement of some of the transportation projects were acknowledged. These skills included “people management”, “communication”, “organisational” and "leadership” as well as many community members with IT skills. "Disability preventing walking and cycling” was recognised as a potential barrier to change. Table 3 gives a summary of the negative aspects.

Participants listed critical infrastructure which would normally be expected; water supply, electric grid, telecommunications, sewage system, waste disposal, road network, railroad, the harbour and the community center. Also in the category of critical assets some participants listed 
the local food supply, radio station, museum, volunteers, the Organic Gardening Group and the Hampden Energy Group. It is interesting that these elements of community were listed among critical assets. It is interesting to note that while many of the positive aspects and assets recognised in the community were shared or personal attributes, most of the negative aspects were attributed to other organizations or members of the general public. This theme seems to indicate that the participants do not see barriers or negative aspects in themselves, but in governance structures and in the wider culture. 
Table 2 Results of Asset Mapping exercise, Session 3. Valuable Assets

\section{Desirable Aspects}

Built Environment

\section{Culture}

Historical District

Rich social history

Best built town in New Zealand

Group of community minded people

Shops

Open-mindedness

Railroad

Small town, community activities

Schools, Hospital

\begin{tabular}{ll}
\hline Location Attributes & Natural Resources \\
\hline Youth and strength, Care and Hope & Land, Climate, Hills \\
Ability to compromise & Ocean, Clean Water, Beaches \\
Passion, Conviction, Energy & Wind, Clean Air \\
Progressive thinkers & Forests, Wood, Stone, Coal \\
\hline Capabilities & Agriculture and Food \\
\hline Belief in invention & Fish \\
Organic gardeners & Good livestock \\
Progressive thinkers & Organic gardens \\
Organising abilities & Good soil \\
Cooking and baking & Wine, \\
Knack for producing alcoholic beverages & Cows \\
\hline Skills, Crafts, Art & Medical, Health \\
\hline Book binder, Writing, Illustrating & Doctor \\
Sewing & Surgeon \\
Woodwork & Natural health practitioner \\
Boot and bag maker & Vibrational therapy \\
Boat builder & \\
Actors and live theatre & \\
\hline Education & Science, Engineering, Construction \\
\hline Math & Builder, Mechanic, Engineer \\
History & Hydrology, Construction \\
Music & Scientific instruments \\
Politics & Architecture, Carpentry \\
\hline Social/Organisational Capabilities & Computers \\
\hline Leadership, Organization & Natural Environment \\
Management & Penguin colony \\
People skills & Forests \\
\hline & Ocean \\
\hline &
\end{tabular}


There were two current events of importance to note at the time of the workshop. A rapid expansion of the export dairy product industry had led to a dramatic increase in the number of dairy farms and the number of cows on each farm. National news stories had been covering the water pollution from the diary industry, and the rural setting of the town meant that most participants would have first hand experience of the environmental degradation from the increased dairy activity. The second event was the announcement of plans by the Holcim company to shut down its cement kiln on the West Coast and to build a bigger plant in Oamaru. The limestone quarry would destroy a local environmental and recreational area, large trucks would move continuously to and from the plant delivering coal and limestone and taking away cement. The community was divided over the costs and benefits of the plant, but the Council was enthusiastic and the company was not discussing plans with the community. The 2008-09 economic crisis stopped the project at the corporate level. 
Table 3 Results of Asset Mapping exercise, Session 3: Negative Aspects and Barriers

\section{Undesirable Aspects}

Governance

Preoccupation with growth \& money

interests

Failure to create environment incentives

Central government obstruction of local

initiatives

Lack of local governance ability to set up

fuel tax or container deposit

Central government, Local council

Central role of fossil fuels

Centralised decision making

Inflexible Council Rules

\begin{tabular}{l}
\hline General \\
\hline People don’t want to change \\
People who want change seen as “scare \\
mongers” \\
Unwillingness to move from comfort zone \\
Debt based money system \\
Holcim Cement Plant \\
Small town, conservative, parochial attitudes \\
Locals don’t accept new people and new \\
ideas
\end{tabular}

Local issues

Apathy

Fear of change

Negative public opinion

Weak social ties

Ignorance

Lack of community spirit

Absentee owners/landlords

Lack of finance or funding

Lack of farmer's market

Dilapidated harbour

High rate of motor vehicle accidents

Environment

Lack of public understanding of global issues peak oil and climate change

Current paradigm

Fear of austerity now outweighs benefit to

future generations

Overexploitation of ground water

Degrading water quality

Poor farming methods, Dairy Farming

Seal level rise could threaten the city 


\section{Results of the project planning exercise}

The final session began with the reading of the Transition Declaration of Independence. ${ }^{8}$ This is an adaptation of the US Declaration of Independence written by Thomas Jefferson and signed by the Second Continental Congress on 4 July 1776. The 1776 Declaration is considered one of the greatest documents of all time. Every member of the Continental Congress who signed the 1776 Declaration knew that they were committing treason against the English Crown, a crime punishable by death. Yet every member of the Congress signed the Declaration. The construction of the declaration is genius. The Declaration makes it clear that the people who have decided to separate themselves from the power, which governs them, do fully understand the gravity of their actions. The Declaration's most powerful element is the list of the "abuses and usurpations" committed by the Crown as justification, according to a higher rule of natural justice, for the extreme action of rebellion (see Appendix H). Dr. Krumdieck had written this Transition Declaration during the design process, but the team had not thought it would be used. However, after the first day of the workshop, it was clear that the sentiment of the participants was aligned with the declaration. The session on the second day was opened with the reading of the declaration and signing by the participants. This activity was a good kick-off to the project planning work of the day in that it created a positive and energy-charged group identity and sense of purpose. One of the local shop-owners and member of the Oamaru Natural Heritage Society framed the signed declaration and put it on his shop wall where it remains today.

People responded well to the structure of the project planning session. All of the participants found a project group to join. All project groups spent all of the session time working on their projects and asking questions of the workshop team about project planning. The best indication of the success of the TransitionScape workshop design was that when the activity was over and the workshop declared ended, all of the project groups kept working. They were finally

\footnotetext{
${ }^{8}$ www.aemslab.org.nz/abode/711/documents/Transition\%20Declaration\%20of\%20Independence.pdf
} 
asked to leave the venue as it needed to be set up for another activity, but they stayed together and moved to nearby restaurants and continued working over lunch.

The projects started during the final session were used as the foundation for a Transition Town Oamaru community. The strategic plan for the TT-Oamaru was produced within 30 days of the workshop. The structure was based on the project plans developed during the workshop with facilitators of each group designated. A Six-month follow-up with the organisers showed that five of the six groups were still actively working on their projects. The projects proposed are detailed in Table 4. Most of the projects on the one-year time frame were realistic with measurable outcomes. Some of the longer-term projects, particularly around energy, rely on achievement of technology and cost conditions, which are beyond the control of the participants or their project team. This further reinforces the idea that the Transition Engineering team needs to become a longer-term participant in community initiated sustainable development projects so that energy and time are directed to achievable goals.

\section{ASSESSMENT OF THE TRANSITIONSCAPE METHODOLOGY}

Assessment of the TransitionScape methodology follows Tippet's criteria for sustainable development. Attention is paid to specific features that fulfil (or fail to fulfil) assessment criteria backed up by participants comments where appropriate. The following discussion and score-card shown in Table 5 are derived from analysis of the video recording of the workshop and discussion of the research team. The participant feedback scores are compiled into Table 6. 
Table 4 Projects, which originated from the TransitionScape workshop

\section{Year 1 Year $2+$}

\section{Group 1 - Infrastructure \& Technology}

1. Connecting walking spaces: walking path to the Heritage area and Penguin Colony for visitors and locals linking camping ground, town centre etc - low carbon transport to heritage attraction

2. Introduction and/or upgrading of bike lanes on roads through out the district
3. Study on the potential production of bio -fuels using local tallow from the freezing and rotational crops for ethanol

4. An Energy demo road-show for local schools e.g. solar panel, solar water heater, wind generator, heat insulation demo, small engine running on bio-fuels

5. Eco - housing demonstration site

6. Coastline protection and the development of local oceanic energy exchange concepts and techniques

7. Public Transit systems investigation
Group 2 - Skills, Knowledge \& Learning

1. School connection: eg. introduction of the story of stuff ... www.storyofstuff.com

2. Centre for environmental living and training or Kids in gardens project

3. Provide film evenings and workshops on topical subjects that relate to the transition town activity
4. Create and promote an energy decent plan

5. Identify, facilitate and promote new employment opportunities appropriate for the delivery of an energy descent and climate changed future.

6. Participate in the HALO (Healthy Active Living Oamaru) awareness campaign

\section{Group 3-Localized Economy}

1. Establish a Farmers Market

2. Get more local produce into the supermarkets

3. Lead group for a registered community kitchen

4. Internet database of locally grown food methods and recipes preparation

5. Local seed bank and heritage tree stock

\section{Group 4 - Restoration and Reclamation}

1. Community permaculture complex, including community garden, heritage fruit trees, coppice and other special purpose tree lots - already underway

2. Conservation of existing native hedge rows

\section{Group 5 - Community Network}

1. Transitions Towns website, Blog, linking with other groups in the local community and New Zealand
3. The introduction of food security "Commons" throughout the District, included in the District land use strategy

Group 6 - Community Governance and Regulation

1. Review current regulatory environment for sustainable activities - already underway.

2. Public Relations: Regular spot on local paper, heritage radio, TV 45south, speaking engagements

2. Build a sound \& positive working relationship with District Council, Regional Council, keeping the Mayor informed - underway

3. Actively engage with the local Iwi ${ }^{*}$ seeking guidance on common partnership issues

4. Address food security, coastal marine reserves for fish stock, hedgerows to maintain biodiversity, preservation of waterways, and water security, coastal erosion, etc

* Iwi is the term relating to tribes of the New Zealand indigenous people 


\section{Engage Participation:}

Participants are engaged within the TransitionScape by the processes of:

- visioning adaptation responses,

- $\quad$ placing these within the 'transition space',

- resource mapping,

- barrier identification,

- $\quad$ stepping into the revisited 'transition space',

- forming new alliances with other members of their community

- and by the planning group exercises.

All of the transition projects originated from the participants themselves, they are not merely deciding their participation in pre-arranged plans. Generally, participants liked the engagement aspects of the methodology (see Appendix I - Feedback Questions). Most participants felt that the structure of the forum allowed a good amount of participation enabling the "enthusiasm and enjoyment [that] comes from participation and eye contact”. Some felt, however, that "more open discussion" or "more participation would be better" but understood that time constraints were a factor. The suggestion of "group sharing, name tags, shared lunch" was made as a means to increase participation.

Although the methodology does have some 'hands on' activity, in the form of writing responses and placing them within the 'transition space' some research team members thought more could be done to fulfil this criterion. Visual learning tools were engaged by use of the slide presentation, three dimensional structure and then two dimensional floor arrangement of the 'transition space'. Creative thinking was enabled via the use of the adaptation scenarios. Participants thought that "the scenarios were very effective" and enjoyed "both information and presentation style”. Attention to the decision making process was made through the use of cards to record participants responses and by the planning exercises. 


\section{Synergies across Scales:}

Although the exercise of asking participants to place their adaptation responses into the 'transition space' was a means of generating recognition and understanding of cross scale principles and utilised transferable tools and materials, this was not supported by a meta data structure or the linking of multiple geographical scales. Some participants also felt "confused where to attach the coloured pieces of paper onto the structure”. On the other hand, discussion about their response and where it might fit with other participants and research team members provided for deliberate and purposeful dialogue. Dr. Krumdieck had previously been involved in "World Café" or open-floor pen and white-board type workshops where people were asked to give ideas or "have your say" about sustainability issues and solutions. She observed that the TransitionScape methodology of having people keep ownership of their responses (by writing on a sticky note) and then to have discussions and be challenged to integrate their responses into a transition space was more productive. In her experience, open discussion forums tend to be hijacked by individuals who focus on expressing their own internal perspective rather than on achieving a group outcome. The purpose of the TransitionScape methodology is to facilitate change from concerned citizens to active groups engaged in improving local sustainability in the face of global issues and risks. Dr. Krumdieck's assessment is that open forum workshops tend to just re-enforce the concern but do not have the structure to create connections between participants needed for cooperative work on team projects.

\section{Integrated and Sustainable Outcomes:}

The focus on sustainability was made explicit throughout the forum, however no explicit criteria for sustainable development was expounded. The resource mapping and scenarios gave a focus on both social capital and environmental integrity. No alternative perspectives were offered on the current situation, however a holistic, systems approach was advocated and encouraged. Many participants were familiar with the facts of the situation with one saying, "I learned nothing new 
about the problems facing us but plenty about strategies for dealing with the problems.” Dr. Krumdieck's strategy for the TransitionScape methodology is aligned with the Transition Engineering approach which focuses on addressing risks of un-sustainability. Thus, the lectures and narrative focused more on changing existing systems and practices to use less fossil fuel than on new technologies or policies to encourage sustainability in general.

\section{Eco-systemic Solutions}

The TransitionScape methodology fared badly in this challenge. The only criterion fulfilled was a focus on ecological/human interaction encouraged during the adaptation scenarios. Although in the lecture the importance of environmental restoration to ensure current and future prosperity was highlighted, none of the participants listed these types of projects in response to scenarios or as project ideas. This is also interesting because one of the main motivating factors for the workshop was concern about Climate Change and environmental degradation. In the lectures Dr. Krumdieck also gave examples of local environmental restoration projects that had been successful in other parts of the country. It could be possible, and there was some observation during the workshop at Oamaru to support this hypothesis, that the people who would be motivated to participate in a workshop on Peak Oil and Climate Change would actually be a different cohort than people who would be motivated to be environmental activists. In fact, Dr. Krumdieck's work with numerous other Transition Town groups around New Zealand and England bears out this observation. In a general sense, the people joining Transition Town movements are motivated by concern about their own food, financial and fuel security than about the protection of the environment. It is plausible that Tippet's projects which were mainly focused on local environmental problems would have attracted a different type of group than the workshop in Oamaru. The research team regard the eco-systemic solutions to still be a key criteria for community transition group workshops, but further design of the activities would be 
needed to draw out the focus of the participants from their own fear of uncertainty to include restorative justice for the environment and future inhabitants of their town.

\section{Develop Stakeholder Capacity}

Whilst not explicitly developing skills within the participants the methodology does enable the acquisition of planning skills (via the planning exercises and project development materials) and systems thinking, albeit implicitly. Education is provided via the presentation of the current situation which one participant thought was "brilliant and inspiring". Use of 'multiple intelligences' and attention to programme development are engaged during the planning exercises. The traditional workshop in New Zealand would reserve most of the time for people to "have their say". It is possible that the participants learned that it is more effective and inclusive for people to "have their thoughts" and then cooperatively share them in a cooperative way that doesn’t require public declaration. 
Table 5 Scorecard assessment of the TransitionScape methodology and workshop.

\begin{tabular}{|c|c|c|c|}
\hline 1. & $\begin{array}{l}\text { Engage } \\
\text { participation }\end{array}$ & $\begin{array}{l}\text { a) Active engagement } \\
\text { b) Hands on process } \\
\text { c) Visual knowledge } \\
\text { d) Creative thinking tools } \\
\text { e) Attention to decision-making }\end{array}$ & $\mathscr{d}$ \\
\hline 2. & $\begin{array}{l}\text { Beneficial } \\
\text { synergies across } \\
\text { scale }\end{array}$ & $\begin{array}{l}\text { a) Cross scale principles } \\
\text { b) Transferable tools } \\
\text { c) Meta data structure } \\
\text { d) Link multiple geographical scales }\end{array}$ & \\
\hline 3. & $\begin{array}{l}\text { Integrated and } \\
\text { sustainable } \\
\text { outcomes }\end{array}$ & $\begin{array}{l}\text { a) Sustainability focus } \\
\text { b) Explicit sustainability criteria } \\
\text { c) Focus on social capital } \\
\text { d) Focus on environmental integrity } \\
\text { e) Combines different perspectives } \\
\text { f) Holistic approach }\end{array}$ & \\
\hline 4. & $\begin{array}{l}\text { Eco-systemic } \\
\text { solutions }\end{array}$ & $\begin{array}{l}\text { a) Spatial design and analysis } \\
\text { b) Ecological design principles } \\
\text { c) Ecological/Human interaction } \\
\text { d) Focus on underlying process } \\
\text { e) Structured design process } \\
\text { f) Life cycle design }\end{array}$ & 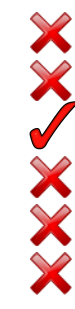 \\
\hline 5. & $\begin{array}{l}\text { Develop } \\
\text { stakeholder } \\
\text { capacity }\end{array}$ & $\begin{array}{l}\text { a) Explicit skills development } \\
\text { b) Incorporated education } \\
\text { c) Use of 'multiple intelligences' } \\
\text { d) Attention to programme development }\end{array}$ & $x$ \\
\hline
\end{tabular}




\section{Participant Feedback}

Participants were asked to rate their experiences of the workshop weekend on a range of aspects of the forum and give comments. About one third of the participants filled out feedback forms. The feedback is shown as histograms of responses to each question in Fig. 6. Each question had a five-point scale response.

Content - How did you feel about the amount of information provided during the forum? Structure - How did you feel about the structure of the weekend forum?

Participation - How did you feel about the level of participation of the weekend forum? Motivation - How did the weekend forum leave you feeling about the future?

Learning - How much do you think you learned this weekend?

Enjoyment - How did you feel about the weekend forum?

Communication - How well did you feel the weekend forum set you express your opinions?

Tools and Aides - How did you feel about the presentation methods and visioning aides? 
FIGURE 6 Participant feedback regarding the workshop in Oamaru

\section{Content Level}

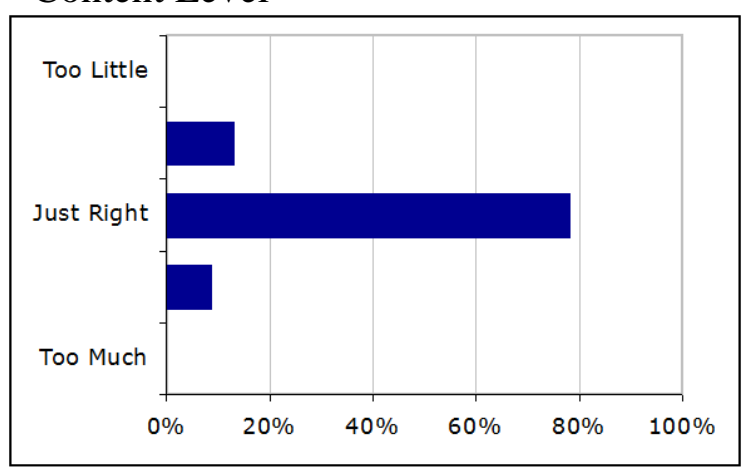

Participation

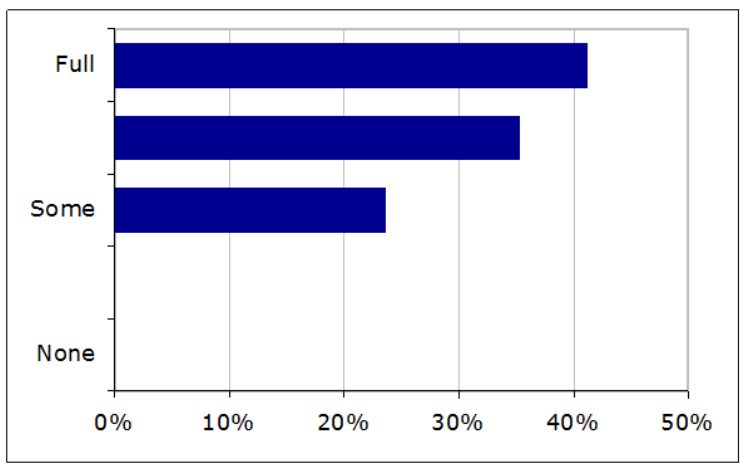

Learning

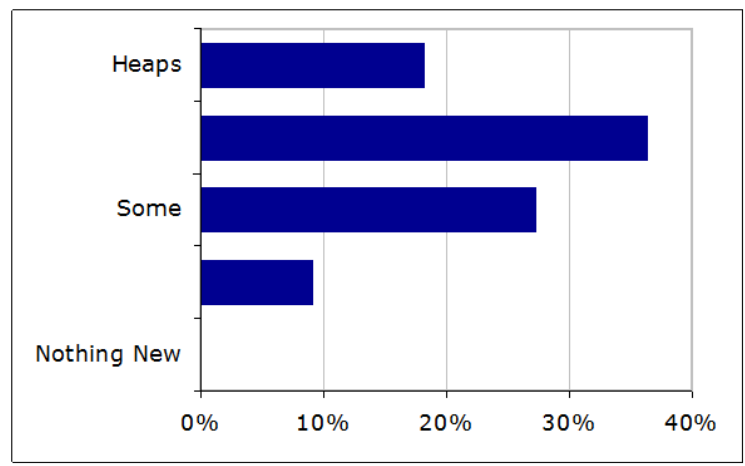

Communication

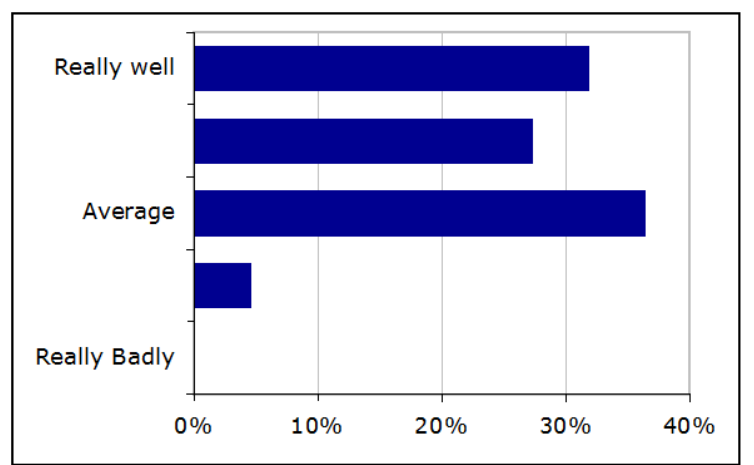

Structure

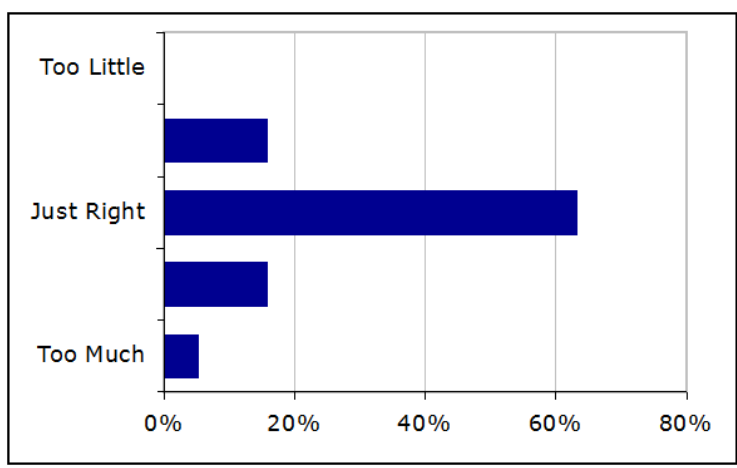

Motivation

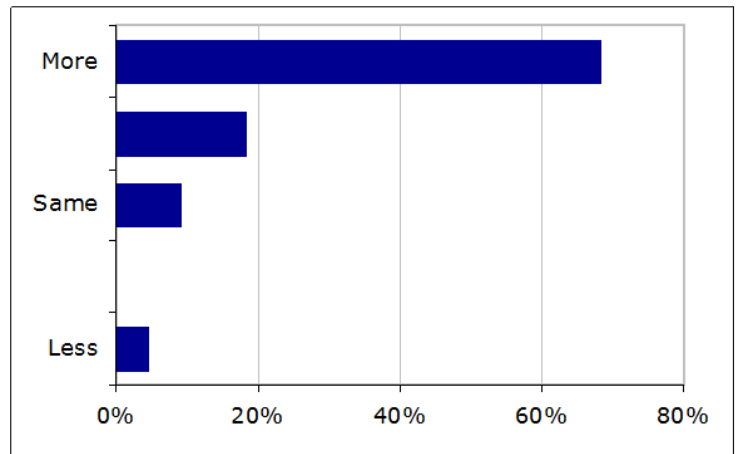

Enjoyment

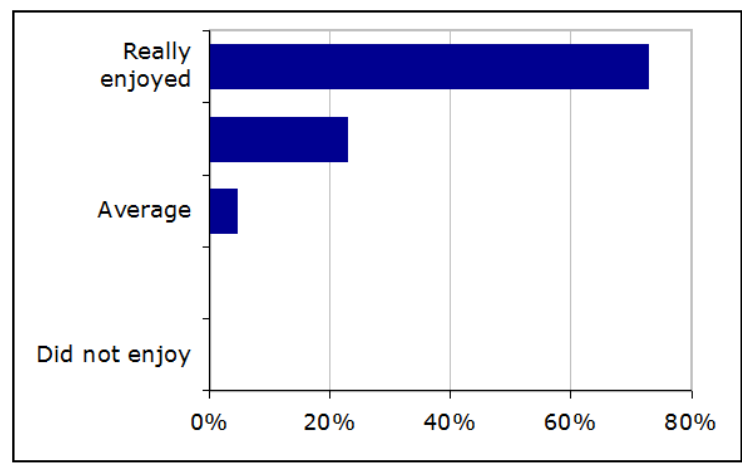

Presentation Methods and Aides

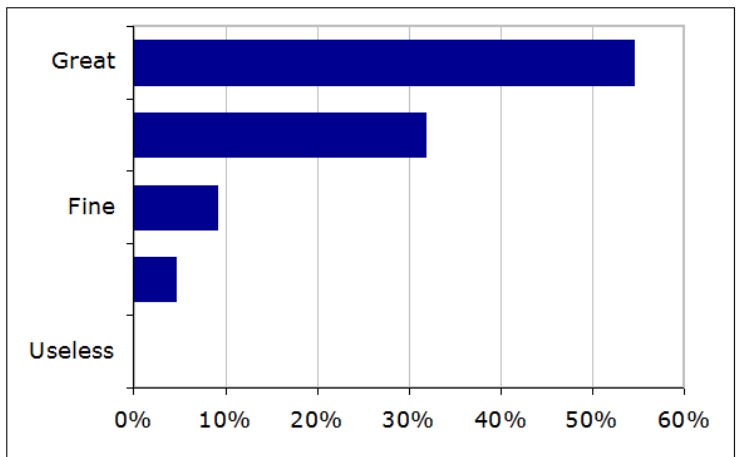




\section{CONCLUDING REMARKS}

A research team of Mechanical Engineers with background in Energy Engineering conducted an active research project on sustainable development, psychological change, and community engagement. The team then designed the TransitionScape methodology with the objective of facilitating community initiated projects that increase adaptive capacity, increase resilience, and reduce the risk exposure to un-sustainable resource use and climate change. The TransitionScape methodology was implemented into a weekend workshop plan with specific activities, presentation materials and props for a group of around 60 participants in the town of Oamaru, New Zealand.

Generally the TransitionScape methodology was a success. On the whole participants seemed to enjoy the experience, feeling more empowered and positive about the future, and many of the design objectives were met successfully, with those not met providing valuable learning experience. Many failures to meet objectives around eco-systemic solutions may have been due to time constraints, both within the design process and the time available during the forum - there is a limit to how much can be fitted into one weekend. A solution is to increase the time allotment; however this may lead to problems of engaging participants for the full duration.

The TransitionScape methodology can serve as a means for generating community driven projects aimed at both increasing community connectivity and development toward achieving desired ends via increasingly sustainable means. The design of the method, although loosely connected with Peak Oil and Climate Change issues in the more general systemic sense can be given a greater focus on specific issues by tailoring the 'worst case' scenarios accordingly.

The great power of the method is that all of the creativity comes from within the community itself, increasing the likelihood of community members to claim ownership of the projects being proposed and increasing the likelihood of their successful implementation. Despite this, many communities will lack the specific expertise to carry out some transportation or energy 
initiatives and it is hoped that use of the TransitionScape methodology will increase connections between participating communities and any necessary outside assistance (planners, engineers, etc).

More work is needed in developing the methodology to meet a greater number of Tippet's criteria for sustainable development. A specific area of work would be within the Eco-systemic solutions challenge and also the addition of some planning learning exercises. Inclusion or reference to an existing sustainable development framework (such as the Natural Step) might also be beneficial, time constraints permitting.

A few participants felt the need for "more open discussion” and "question and answer sessions” which again could be included, time constraints permitting. One means by which this could be achieved would be the inclusion of an 'unofficial' open discussion during one of the lunch breaks thereby increasing participant interaction and connectivity whilst not detracting from the structure of the forum as a whole. This particular workshop did not include group lunch and participants left the venue. The action research team would have liked to have a follow-up workshops in the town to help with development and management of the projects. In general we are satisfied that the TransitionScape methodology developed and trialled in this research is a good foundational tool for the emerging field of Transition Engineering.

\section{REFERENCES}

Campbell, C.J., Laherrere, J.H., (1998). The End of Cheap Oil. Scientific American 278, 78-83.

Chermack, T.J., Lynham, S.A., (2002). “Definitions and outcome variables of scenario planning”, Human Resource Development Review 1, (3) p.16.

Costanza, Robert and Daly, Herman, "Natural Capital and Sustainable Development”, Conservation Biology, Vol.6, No.1, (1992), pp.37-46 
Dale, M. Krumdieck, S. Page, S. Mulligan, K., (2008) “An Ecological Planning Approach to Community Based Sustainable Development”, $3^{\text {rd }}$ International Conference on Sustainability Engineering and Science (9-12 December 2008 Auckland, New Zealand). Gunderson, L., Holling, C.S. (2002). “In Quest of a Theory of Adaptive Change” in Gunderson, Lance; Holling, C.S (eds); “Panarchy”, Island Press.

James, S., Lahti, T., (2004). “The Natural Step for Communities”, New Society Publishers, Chapter 17, pp.203-221.

Kubler-Ross, E, (1973). “On Death and Dying”, Routledge.

Krumdieck, S. (2011). “Transition Engineering of urban transportation for resilience to peak oil risks”, (11-17 Nov 2011, Denver, CO) Proceedings of the ASME 2011, ICEME2011-65836.

Krumdieck, S., (2011a). The Survival Spectrum: The key to Transition Engineering of complex systems, (11-17 Nov 2011, Denver, CO) Proceedings of the ASME 2011, ICEME2011-65891. Roseland, J., (1998). “Toward Sustainable Communities: Resources for Citizens and Their Governments”, New Society Publishers.

Tedeschi, R. G., Calhoun, L. G. (1995). Trauma and transformation: Growing in the aftermath of suffering. Thousand Oaks, CA: Sage Publishing.

Tippets, Joanne et al, (2007). "Meeting the challenges of sustainable development - A conceptual appraisal of a new methodology for participatory ecological planning”, Progress in Planning, 67, pp.9-98 


\section{APPENDICES}

\section{Appendix A - Forum Timetable:}

\section{Saturday 15th \& Sunday 16th March 2008 CLIMATE DISRUPTION - TRANSITION TOWNS - ONE RESPONSE}

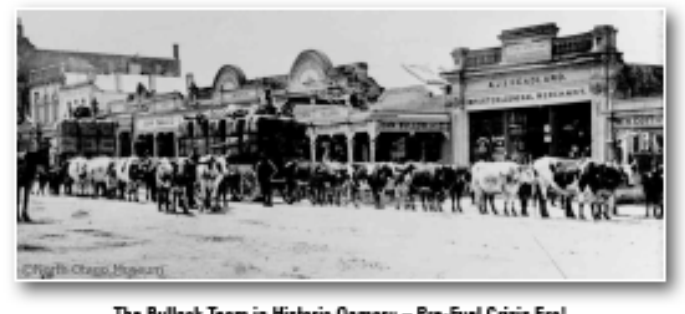

The Bullook Team in Historin Oamaru - Pre-Fuel Crizis Era!

The Transition Town initiative has its origins in Kinsale, Ireland and has spread rapidly around the world. A Transition Town or community evolves when a group of like minded individuals come together to collectively look Peak Oil and Climate Change squarely in the eye. They try to discover and implement aspects of life that we need in order to sustain and thrive, and also ask questions about mitigating the effects of Peak Oil and drastically reducing carbon emissions to mitigate the effects of climate change.

\section{Dr. Susan Krumdieck Ph.D. ENERGY SYSTEMS RESEARCHER}

Was originally from the University of Colorado and is now senior lecturer, Department of Mechanical Engineering at Canterbury University where she is an engineering researcher in energy systems.

Susan's work also involves the study of pre-oil settlements as well as looking at movements like the Eco-Village, TransitionTowns, Re-Localisation and Permaculture.

\section{TIMETABLE}

\section{Saturday 15tb March 2008}

10.00am Welcome

10.15am Dr. Susan Krumdieck

From Pre-Oil Settlements tbrough to "Future" versions of settlements that bave adapted their oil based forms to renewable energy.

11.15am Break (morning tea)

11.30am Dr Susan Krumdieck ....continued.

$12.30 \mathrm{pm}$ Lunch

1.30pm Dugald MacTavish \& Hampden Community Energy Members Local Case Study: the challenge of making it work in Hampden.

2.30pm Break (afternoon tea)

3.00pm Transition Towns - One Response Discussion

4.30pm Finish

Sunday 16th March 2008

10.00am Welcome

10.15am DrSusanKrumdieckwithstudents from Canterbury University Transition mapping of Oamaru with application to otber areas.

11.00am Break (morning tea)

11.15am Planning Session. .. continued. 12.30pm Finish 
Appendix B - Session Plan:

\begin{tabular}{|c|c|c|c|c|c|}
\hline DAY & $\begin{array}{c}\text { SESSION } 1 \\
\text { 10:15-11:15am }\end{array}$ & \multicolumn{2}{|l|}{$\begin{array}{c}\text { SESSION } 2 \\
\text { 11:30-12:30pm }\end{array}$} & $\begin{array}{l}\text { SESSION } 3 \\
\text { 1:45-2:45pm }\end{array}$ & $\begin{array}{c}\text { SESSION } 4 \\
3: 00-4: 30 p m\end{array}$ \\
\hline Saturday & $\begin{array}{l}\text { Setting the Scene: } \\
\text { 1 hour lecture, S. Krumdieck } \\
\text { 1. Why do we have to change? } \\
\text { - Peak Oil } \\
\text { - Global Climate Disruption } \\
\text { - Infrastructure Security and Sustainability } \\
\text { 2. How are we going to change? } \\
\text { - Paradigm shift away from growth to } \\
\text { - Sustainability } \\
\text { - Examples from anthropology }\end{array}$ & \multicolumn{2}{|c|}{$\mid \begin{array}{l}\text { Your Response: } \\
\text { 4 Adaptation Scenarios: } \\
\text { - } \\
\text { - } \text { Dwindling Oil Supply } \\
\\
\text { - Supply } \\
\text { - Environment, Water and } \\
\text { - } \text { Food } \\
\text { Social Degradation }\end{array}$} & $\begin{array}{l}\text { Dugald MacTavish \& } \\
\text { Hampden Community } \\
\text { Energy Members } \\
\text { Local Case Study: the } \\
\text { challenge of making it work } \\
\text { in Hampden. }\end{array}$ & $\begin{array}{l}\text { Acceptance and Hope: } \\
\text { Identification of positive and } \\
\text { negative values and assets for } \\
\text { Oamaru } \\
\text { Adaptation Scenario } 5 \text { - } \\
\text { TransitionTown Oamaru }\end{array}$ \\
\hline Sunday & $\begin{array}{l}\text { Launching the Transition Project: } \\
\text { Presentation of TransitionScape } \\
\text { Group work identifying: } \\
\text { - Barriers to change } \\
\text { - Assets } \\
\text { - Expertise needed } \\
\text { - Government assistance } \\
\text { - Livelihood assessment }\end{array}$ & & $\begin{array}{l}\text { Prob } \\
\text { Curr }\end{array}$ & $\begin{array}{l}\text { lems Identification and Per } \\
\text { ent Position } \\
\text { ning Options }\end{array}$ & sonal Response \\
\hline
\end{tabular}


Appendix C - Poster Design:

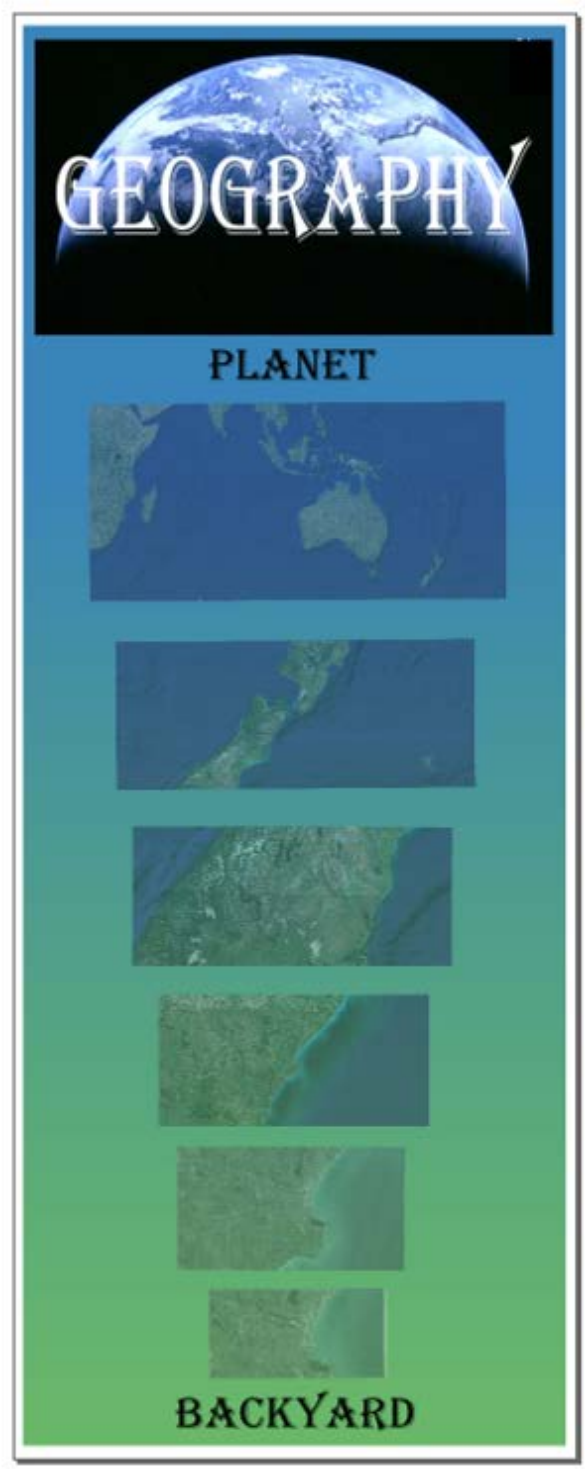

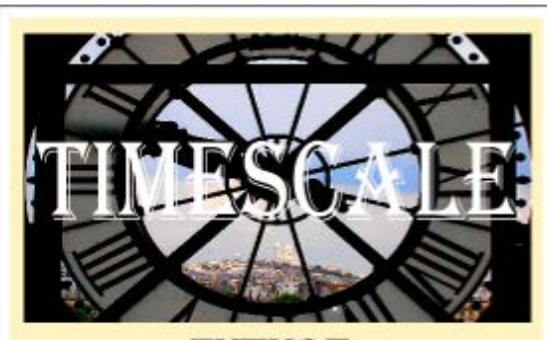

FUTURE

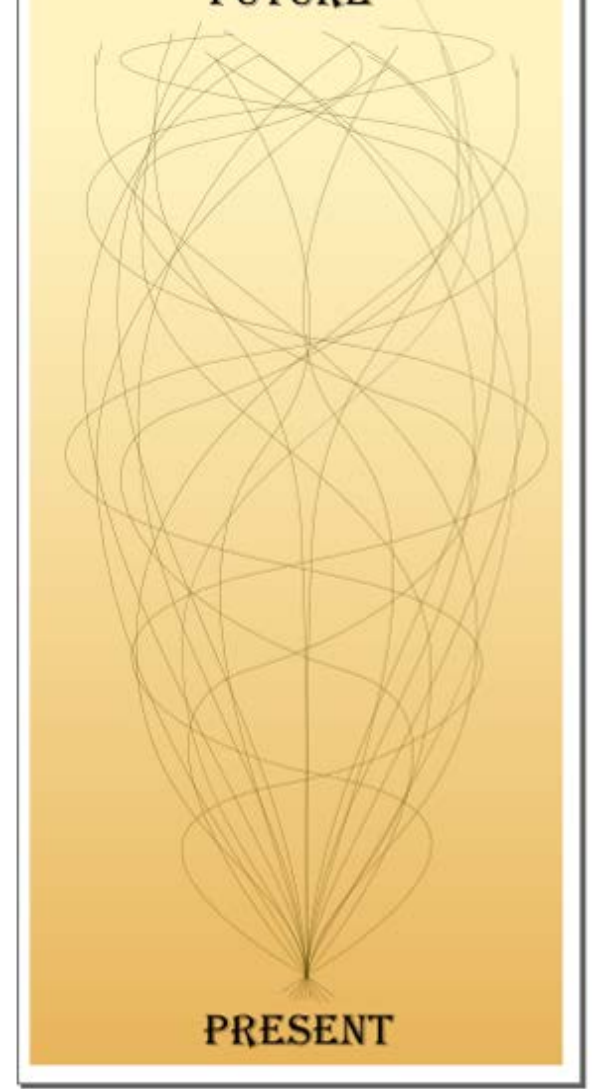

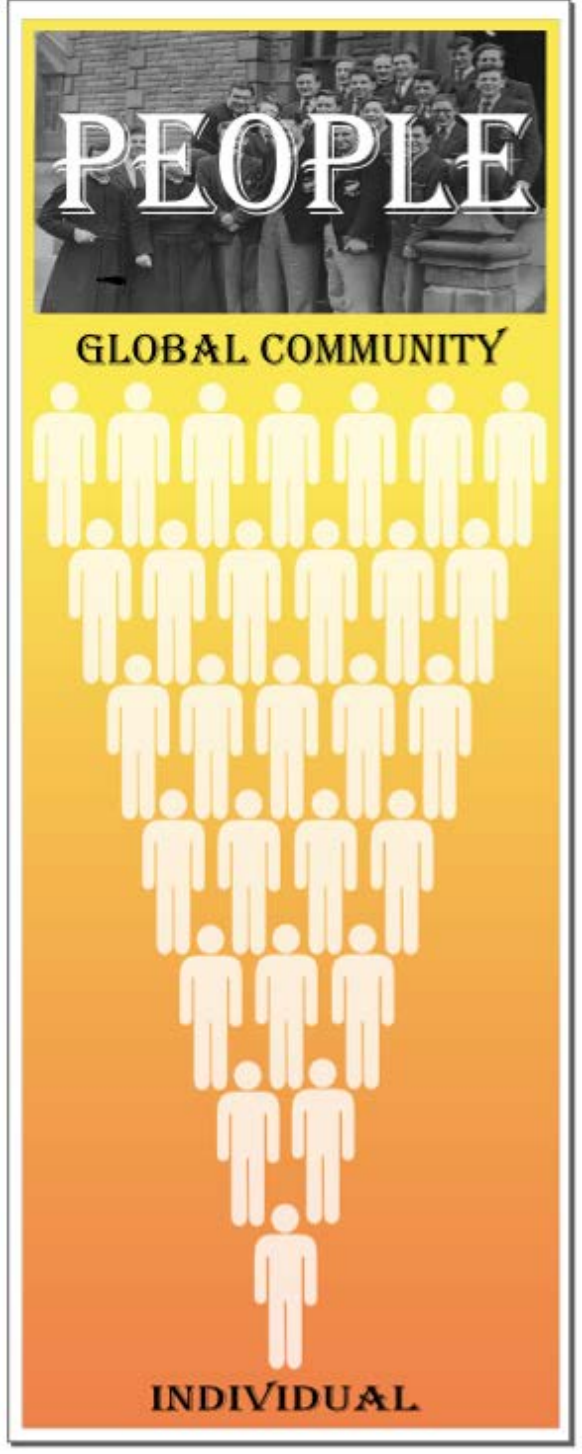




\section{Appendix D - Pop-Mythology PowerPoint Presentation}
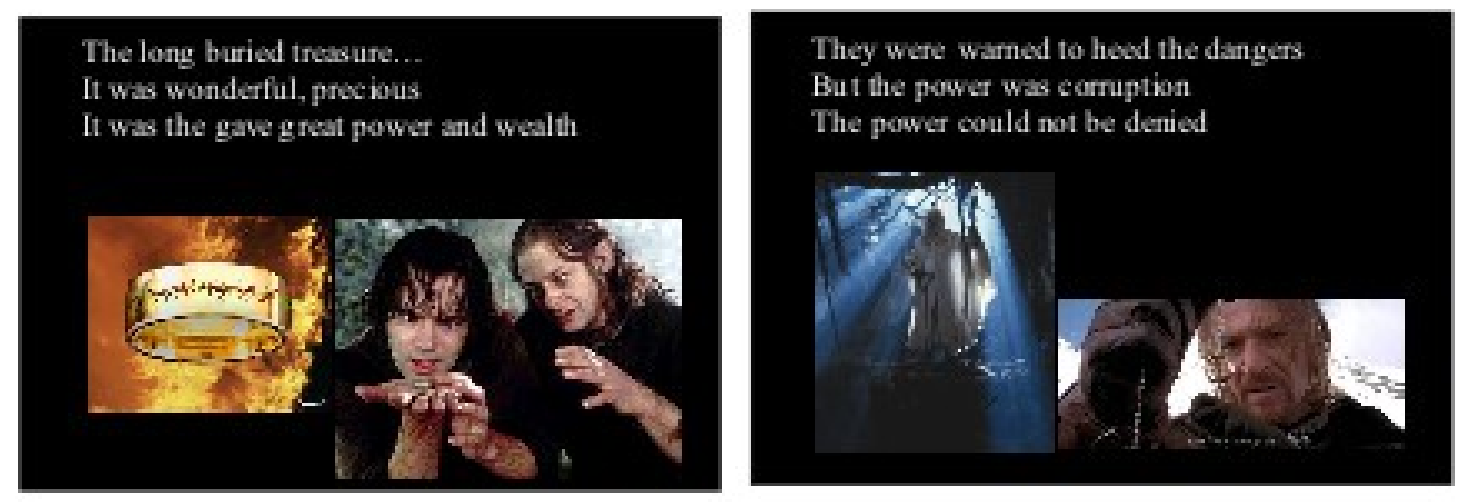

The Dark Power

Bocame a hunger, a nead

Became a driving force of confl it and hatred
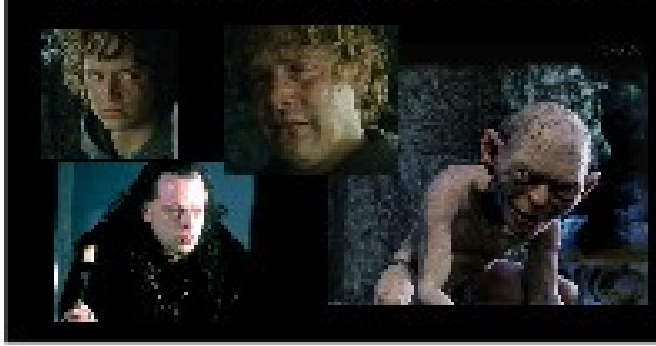

The Power became Destruction

Dark was rising, Hope was fading

Courage was failing

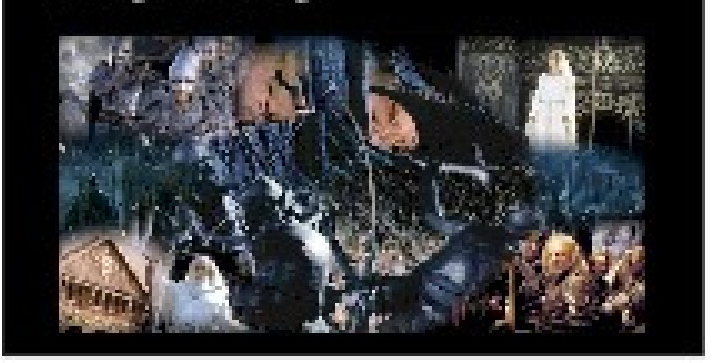

The Last Hope was small

An imposible task for those without power b rid the wor $\mathrm{k}$ of the power that was destroying it
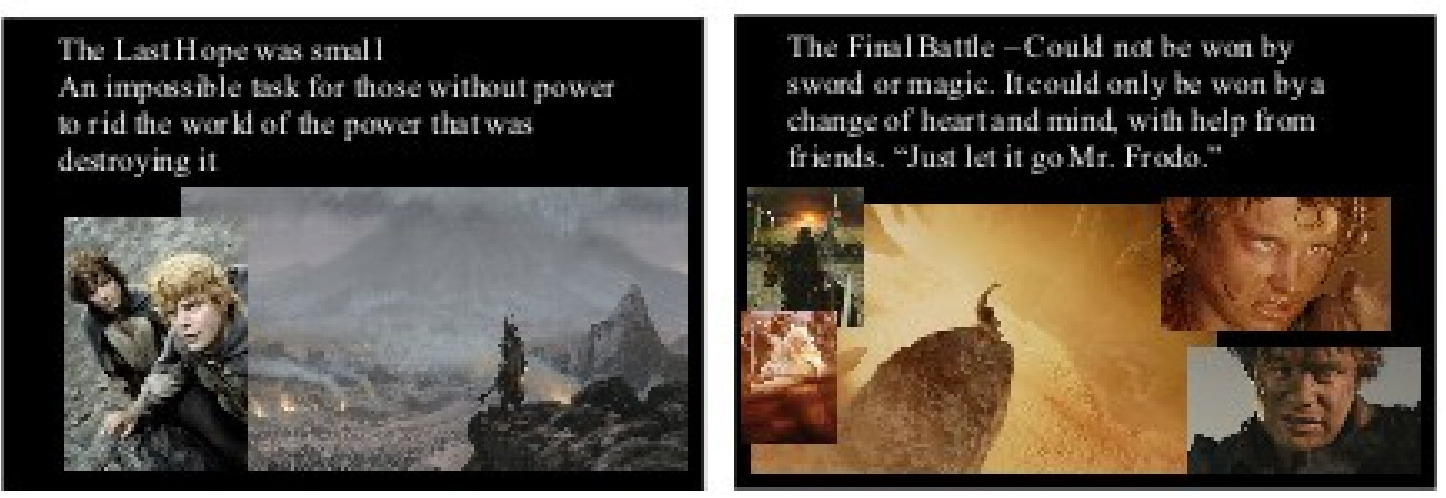


\section{Appendix E - Stages of Grief for Energy and Environmental Issues}
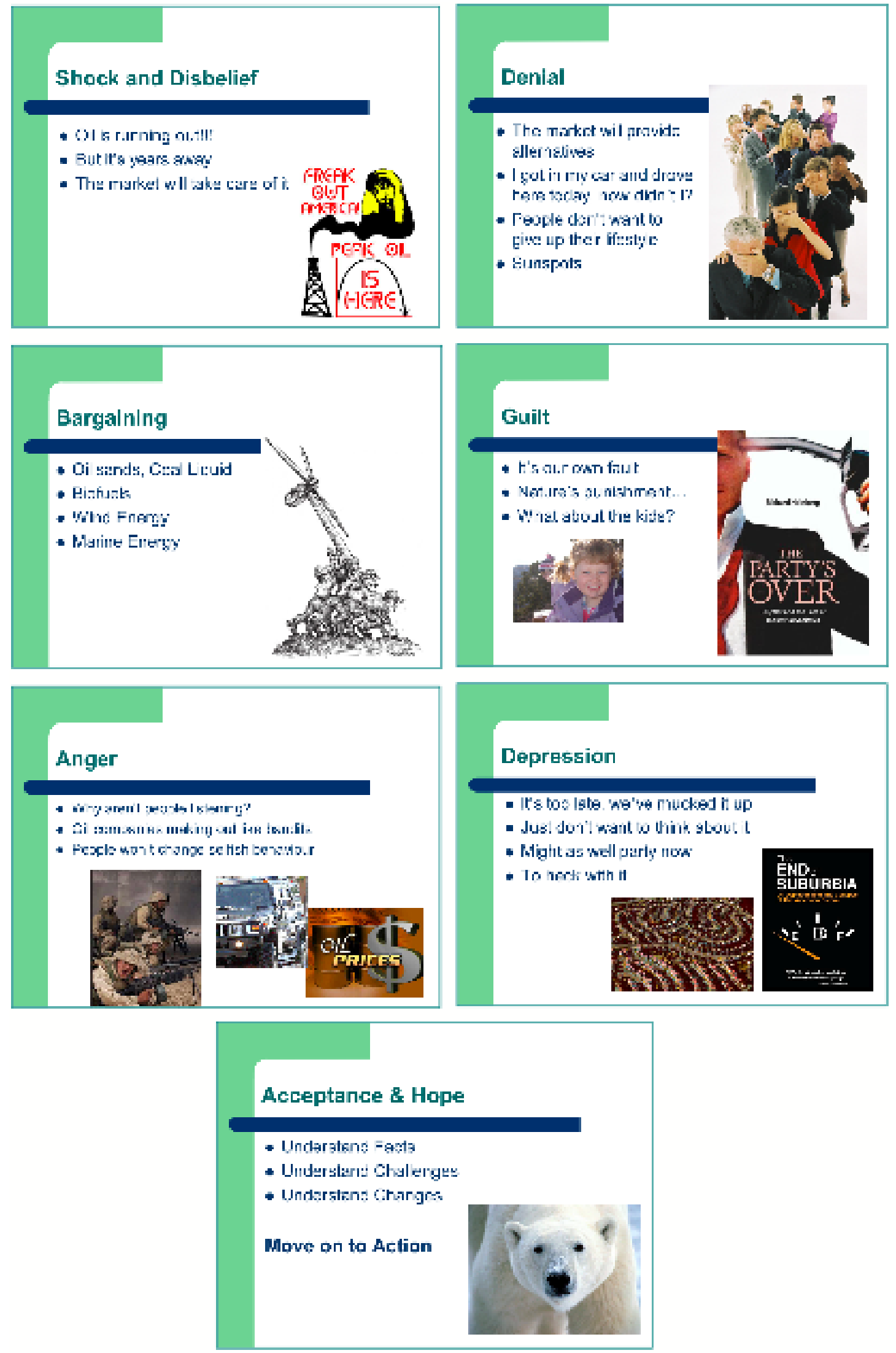


\section{Appendix F - Adaptation Scenarios:}

\section{Scenario 1. Adaptation - Oil Supply: (Orange Cards)}

We are in the grip of another a serious fuel shortage.

It's all the news, the price of petrol has nearly doubled again in the past six months. The local petrol station has a sign that says people should only buy fuel if they really need it, there's enough for a few days, but purchases are limited to 10 litres, with a price of $\$ 6.80 /$ litre. The oil shortage news overseas is pretty bad too. The USA has broken with the IEA and has bid up the price of oil to $\$ 450 /$ barrel, thus capturing supply that was previously destined for other countries, including New Zealand. The prospects for further fuel shipments are looking grim. The government announced it will shortly issue fuel rationing coupons, and is reserving fuel for emergency services and agricultural harvesting. The government is seeking fuel shipments from Australia but no deal has been reached - and frankly no one expects Australia to help out. They are having fuel shortages all over the country as well.

School busses are not running. City busses are running on reduced schedules. This is the fifth major shortage this year so far, and between the major shortages, the supply is still reduced to where people are limited in what they are allowed to purchase.

The rubbish pick-up has been reduced to once per month. The supermarket shelves are getting empty again.

----- What have you and your family done to cope with this situation? Give examples of your own activities that require travel from home, and how you have dealt with having unreliable and scarce fuel?

-What has Oamaru done to deal with this situation?

\section{Scenario 2 Adaptation - Electricity Supply: (Yellow Cards)}

It's another power failure.

You get out the battery radio to see if it is a rolling black-out with a time announced when power will be restored, or if it is another grid failure due to high loads on the grid, and not enough generation. Since the North Island gas supply ran out, the peak demands, especially in the winter mornings and evenings have brought the grid down at least once per week since May. The price of electricity has also gone quite high, especially since the Huntly coal power plant was decommissioned. The power companies have responded by setting up rolling black-out plans, so that the same people don't loose power every time, where the grid is weak. It's all the news that the power companies aren't letting people know ahead of time because then people use more power ahead of time, and cause random outages. The energy minister was just on the radio explaining that the drought and resulting low lake levels mean that hydro generation cannot be increased, or water supplies may be threatened.

With the recession and collapse of the international tourist industry, there is not enough money to build new power plants, but there really aren't many suitable resources to use at any rate. The geothermal fields seem to have been fully tapped. The head of the electricity commission has been on the radio and TV nearly every day explaining that there should be enough power to meet everyone's basic needs at all times, but people need to use as little power as possible during breakfast and tea time to do their part to prevent black-outs. 
Frozen foods are stocked at only one grocery store, as they have a back-up generator. There was a big push to put in more wind turbines, but the funds seem to have dried up to maintain them, and they don't seem to have much of an impact on alleviating the power shortages. The Prime Minister is urging people not to use electricity for heating, including heat pumps. Use electricity only for critical needs.

What have you and your family done to cope with this situation? Give examples of your own activities, residential and business, and how you have dealt with having unreliable electric supply?

-------What has Oamaru done to deal with this situation?

\section{Scenario 3. Adaptation - Environment, Water, Food: (Green Cards)}

It's the fourth "drought year" in a row.

Several irrigation schemes with reservoirs were built to try to capture the rain when it does fall, but even they are dry now. The dairy herds have dwindled down to just a few. Fontera went into receivership several years ago and has shut down its milk processing facilities. You read an article that said that the run-away $\mathrm{CO}_{2}$ emission growth had finally started to slow down a bit, probably because of the fuel shortages and collapse of America's power grid which hasn't been able to be restarted since the eco-terrorists blew up several strategic coal power stations. Now the atmospheric CO2 is around 590 ppm, there hasn't been ice in the Arctic for two years, and it looks like what's left of Greenland's ice is just pouring into the sea - maybe a few years left is all. The sea has definitely come up from where the old pictures show it used to be. There was another boat of Australians that turned up on the West Coast, and the refugees from the Pacific Islands have over-run the military blockades in Auckland. There haven't been any penguins seen for several years. With the collapse of fish populations around the world, you're glad that there are still a few fish off our coast. But it's a worry that some scavenger fishing boat will come in and wipe out what's left. The pine forests have dried up and were harvested before they burned up like the Nelson fire disaster. But now with the old clear-cut plantations and the grass that has largely dried up, the dust storms are a huge problem. The local orchards and most of the market gardens are really struggling. At least there's the goats. Seems like they can get sustenance from rocks. Not much good for eating, but there's a bit of goat cheese at any rate, and the olive trees seem to be able to tolerate the heat and low moisture.

Your son's sixth grade class celebrated the lifting of the travel ban because of the latest flu epidemic with a picnic along the river. The teacher brought along a photograph that her grandparents had and showed the kids what it used to look like with water in it. None of them have ever seen water in the river. The water table is so low the well water is starting to get salty. Too bad the desalination plant had to be closed down after spare parts couldn't be found. It was a miracle the old thing had kept running so long as it had. No. 8 wire Kiwi ingenuity probably.

------ What have you and your family done to cope with this situation? Give examples of your residential and business activities, technologies you use, and relationships you have with your neighbours.

What has Oamaru done to cope with this situation? 


\section{Scenario 4. Adaptation - Social and Government: (Pink Cards)}

Another call for an election?

The last one was only 4 months ago! It seems that the only thing the politicians do any more is try to blame the economic problems on the previous government if they're in power, or blame it on the current government if they're out of power. Do people really care anymore? There doesn't seem to be anything the government can do anyway.

Manufactured goods from overseas are too expensive, but we don't seem to have anybody in this country who knows how to make anything anymore after all the production moved off shore all those years ago. Now that the bloody Holcim Cement plant has packed up and gone, the population will probably drop further.

It looks like your neighbours left during the night. The father was still employed at the school, but there was no way they could afford the mortgage payments, and no way to sell the house for anywhere near what they owed on it. So, they just walked away. The bank will repossess it, but then it will just sit there and rot like the others, with windows getting broken out, and looters going in to take anything that might be sold off. The best thing about the collapse of the property market is that at least rent has gone down. However, all the old folks who were counting on that investment are now howling at the government to bring back the superannuation. Of course, the government's been running at a deficit for so many years that money seems like a silly useless thing anyway. It certainly isn't worth anything to the rest of the world! Pacific Peso indeed.

There's another news story about the number of elderly people being found starved or dead of heat stroke in Auckland. Don't all those older people have families? Sure, most people with any skill got out when they could and went to Europe or China to try to get a job, but you'd think they could send some money home.

Oh Great! Another story on the radio about another university closing down. The universities tried for a while to keep up their student numbers by advertising to foreign students. But with the third global economic depression, that's all but dried up, and New Zealand just doesn't have the number of young people to justify keeping all the universities open. That proposal by National to try to get retired people back into school and back into the work force was precious. Without decent medical care, and with the new tropical diseases and flu that roar through the country every year, the old folks aren't living long enough to take on a second career anymore. And the Greens - if they could ever stop saying "told you so" and try coming up with some ideas about how to get young people to do something besides smoke dope and smash in shop windows, that might be useful. No money for more police? We can't work to provide taxes with all this mayhem! Then there's the ultimate solution from the NZPower party - confiscate all of the property and accounts from the immigrants, and put them on boats off the islands back where they came from.

All the different governments have tried the types of public works programmes that worked way back in the Great Depression last century, but those people were different somehow, they were younger, more connected to families and communities, and most of them actually knew how to do something like farming or carpentry. At least we haven't gone the way of the Aussies with assassinations and gangs and warlords taking over.

Yet. 
What have you and your family done to cope with this situation? Give examples of your residential and business activities, technologies you use, and relationships you have with your neighbours.

What has Oamaru done to cope with this situation?

\section{Appendix E - Transition Scenario:}

\section{Scenario 5. Transition to Sustainability: (Purple Cards)}

There's a nice little town on the sea.

The oil shortage, power system insecurity, and economic troubles have really hit the country and the world. The droughts, floods, storms ecosystems collapse and diseases make it seem like troubled times indeed. But Oamaru is doing ok. Sure, back in the day, the "Economic Growth" culture tried to portray the transition movement as ignorant or Greenies, or any other radical stereotype. But it wasn't long before the benefits started to show up in many ways, and so many other towns were rushing to catch up, that the government had to start cooperating.

The biggest difference between Oamaru and a place like, say, Queenstown which is now nearly a ghost town, is the transition paradigm shift. The things the people did weren't really so high tech, it was the idea to do them that was so revolutionary.

The transition committee actually wrote a declaration of independence from the Growth Economy. They recognised the Tragedy of the Commons that has brought about such total environmental ruin around the country and the world, and they formed up the Commons Council to manage and limit use of resources.

The transition committee soon became an organisation of people from the region with a wide range of backgrounds and talents. The committee organised research into other communities that seemed to be also declaring their intention to shift their paradigm from growth in consumption to sustainability of value. They learned a lot, but decided in the end that the transition would need to be a journey and it needed to start now, with them.

They organised a weekend forum with a research group from a university, and that forum became anniversary date, the recognised beginning of the transition that led to Oamaru and the surrounding area's resiliency and adaptation through the climate disruptions, political instability, fuel shocks, and power shortages that have caused the collapse of growth economies all over the country and the world. In fact, many transition committees from other communities came to Oamaru in the early days to discuss what the town was doing, and find out how they were doing it. Now there is a confederation of Free Places where the local civic structures have the councils and courts for continuity of the commons that were first pioneered in Oamaru. It turned out that all of the good ideas and good intentions of individuals or groups to "live sustainably" could not produce the transition paradigm shift without the CCCC governance structure. This structure allowed freedom of individuals and organisations to profit from their own talents and productivity, but within the context of the continuity of the community resource base and sustainability of the environment.

The projects started back then were usually seen as "non-economic" according to the growth paradigm, but they have been critical to the town's current viability. 
The committee brought in marine scientists from the university to survey the coastal ecosystem and to map out the areas that should be set aside as "no use" sanctuaries. These areas slowly recovered and became well-springs of marine life for local markets and trading to other Free Places. The Marine reserves are now fiercely safeguarded by the whole community. Similarly, the committee brought in scientists to develop reclamation and restoration plans for the rivers, hills, coast line, and agricultural areas. Riparian areas were stabilized and protected, the hills were carefully cultivated in native canopy plants which stabilized the local hydrological cycle. Drainage canals were sealed and raised up to raise the water table.

Agriculture was actually one of the easier areas for the paradigm shift. People had worried that the shift to industrial agriculture for economic growth would be difficult to counter and repair. However, it turned out that the benefits and satisfaction of farming had been so stripped away by the industrial agriculture practices, that many farmers gladly made the shift to community continuity farming. The local CCCC governance structure required that all farms must submit their practice to scrutiny by the committee and sustainable farming experts from the university. All farms were required to develop practices that improved their land and water quality. Many of the foreign farm landlords sold out, but a new generation of farmers took their place and the revolution has been remarkable.

In the town, Permaculture teachers and practitioners have turned the urban landscape into an integrated production and waste management area. Another important move was the establishment of a seed and plant bank at the botanical gardens. Biological diversity of all types of crops were sought out and continuously cultivated in the community gardens to ensure adaptability to climate changes. Poultry and other animal husbandry operations were also required to maintain maximum genetic diversity in their stock. This move alone has been responsible for the farms of Oamaru making it through the weather disruptions and diseases epidemics that have wiped out the monoculture operations around the rest of the country. Now Oamaru's diverse stocks are used as starter populations for other Free Places.

Transition of the automobile culture has been one of the biggest achievements. Of course there are still vehicles in the town and on the farms and going between the towns. There are even the race car club and the 4 wheel drive club for recreation. But the new form of the town, and the new transport service organisations have replaced the old individual car ownership system. It started with institution of a fuel retail management system in Oamaru, where the shipment of fuel into the region was deliberately controlled, and distribution to customers set up as a reservation system. Very quickly, and several years before the oil shocks that devastated the rest of the country, whole different systems for transporting goods and accessing activities arose in and around Oamaru. It turned out that, with the help of the transport engineering research group at the university, the energy efficiency of daily life in the region was improved to the point where Oamaru functioned just fine on $20 \%$ of the oil it was consuming at the time of the declaration. Very few people now own, nor even want to own a car. But everyone agrees that the nightmare of automobile domination, and the health and safety plague that went with it is now over. Yes the town looks quite different from the car old days, with the unique neighbourhood clusters and gardens. But you really can't find anyone who wishes for the way things used to be.

The power system break-down that has plagued the rest of the country has been managed well by Oamaru, thanks to their community response system, and all of the changes in households and businesses over the years. A true transition from the old "we need more capacity to meet our growing demand" way of thinking. It started 
with the pilot project of the demand response device, and the contract with the lines company and Meridian. The town and surrounding region got a guarantee that the power situation would be communicated to the people, and they in turn would adjust their consumption to match supply. This has meant that Oamaru has been nearly free from the disruptive power black-outs that have caused such problems elsewhere, and it also kept the price under control. This system was instrumental in shifting the paradigm of the people from "demand" to "need". This awareness changed the way people used power in profound ways. New businesses and services were started up that provided value while reducing power consumption.

Of course, local markets and local manufacturing, local re-use of packaging and recycling of materials have all flourished under the new paradigm. Now it all seems perfectly sensible, but one can reflect back on the huge effort and struggle that was involved in this transition. The first small step was banning of the plastic shopping bags and a 50 cent deposit on all containers, e.g. milk bottles, jam jars, yogurt pottels, cereal boxes... All manufacturers with a registered trademark were required to accept back these containers, as they were not allowed to go into the community compost or incineration plant. The revenue from the deposit was used to provide local currency grants for local producers that established products with re-usable containers. Now, the market is full of local produce preserved in Agee glass jars at the local cannery or by cottage dairy crafters. People walk or bike to their local market centre, bakery, veggie stand, butchery and tea house nearly every day for bread and a chat with neighbours.

List all of the reasons you can think of why the transition measures that these Oamaru citizens have taken COULD NOT BE DONE now. 


\section{Appendix G - Participant Responses to Collapse Scenarios}

\section{Demand Management:}

Transport mode change - bike, walk, etc. Ride sharing

Waste reduction

Cars only for essential trips

Work from home

Reduce electricity demand - sleep longer in winter, cook every 3 days, night store

Collect rainwater

Grey water recycling

Reduce water usage

Low water crops

\section{Infrastructure and Technology:}

Build up rail network

Prospect for more oil

Bio-fuels

Wood burners

Solar heating

Housing insulation

Diesel generator

Low energy food preservation

Community owned energy generation

Wind power

Hydro power

Collect rainwater

Grey water recycling

Composting toilets

Water desalination plant

Solar desalination plant

Grow our own medicines

Security - build fences, build walls
Knowledge, Skills and Education:

Food preservation

Conservation education:

Water

Electricity

Energy

Environmental

Get experts in for help with planning

Foster traditional crafts

Cooperative skills

Re-skill - teach carpentry, other useful skills

Teaching horticulture

Community connection to reach out to

youth and apprentice them

Develop a community knowledge bank and information bank about local and historical knowledge

\section{Local Produce and Markets:}

Market gardens

Farmers market

Community garden

Home grown food

Permaculture

Use local resources locally

Don't export local resources

\section{Restoration and Reclamation:}

Environmental conservation

Permaculture techniques

Drought resistant plants

Biodiversity 


\section{Community Networks:}

Ride sharing

Shared use of community resources

Communal shopping

Community meals

Care of vulnerable

Community food storage

Community owned shop

Family and Friend Networks (to reduce power demand)

Watch movies together

Children play board games

Share evenings with neighbours

Counsel others to not panic

Shared Meals

Fellowship in community

Barter, local currency

Share trading

Foster traditional crafts

Creating new networks

Community groups

Cooperative skills

Neighbourhood collectives

Form local neighbourhood groups for

security - community watch

Look after unfortunate people

Form militias, security cooperatives

Community gardens

Community connection to reach out to

youth and apprentice them

Self-organization

Multi-generation living arrangements

\section{Re-localising Economy:}

Work from home

Reduce debt, eliminate debt

Barter, local currency

Share trading

Foster traditional crafts

Reduce tax collection and close

unnecessary buildings

Self-organization

Use local resources locally

Don't export local resources

Local justice systems

\section{Governance and Regulation:}

Work from home

Prioritise/Restrict fuel use

Growth limited to region's carrying

capacity

Protect water sources

Regulations to allow rain water

collection,

Prioritize water use

Rationing of water, provide water tanks

for potable water

Banning Flush Toilets

Reduce tax collection and close

unnecessary buildings

Form our own local governance

Self-governance

Self-organization

Use local resources locally

Don't export local resources

Local justice systems 
Appendix G - Planning Exercises:

\section{Asset Mapping:}

\section{$\underline{\text { Stock Take } 1 \text { - Assets }}$}

Penguin Club

Small Town

Services are nearby, good public services

Affordable Lifestyle

Local ownership of Assets

Oamaru Whitestone Civic Trust

Heritage Buildings

Rail Line, Western Escarpment

Library, Art Gallery, Museum

Waitaki Resource Centre

Infrastructure, Resource Recovery Park

Water and Waste Locally Maintained

Education, School Library

Harbour

Local Arts and Crafts

Heritage Skills

Great Quality of Life

Creative People

Medical and Dental

Radio Station

\section{Attributes}

Controlled Development

Government, Community Network

Precinct

Low population growth, Low population

density

Peace and Quiet

Low Crime

Cohesion and Civic Pride

\section{Culture}

Community Spirit

Mix of people

Know Everyone

Realistic Outlook

Culture, theatre

Village, Independence

Sense of being able to be a part of and contribute to the community

Easy lifestyle

Community Activities

\section{Natural Resources}

Climate, Nature

Space, Clean Air, Clean Environment

Totara Soil, Wood for heating

Good soil, Good water

Sea, Harbour, Fish

River, river flows

Wetlands, wildlife

Penguin Colony

Agricultural Land near town

Environment Recovery Park

Organic Farms 


\section{Council}

Expansion mentality and emphasis on heavy industry

Conservativeness

Attitude toward sustainability, understanding sustainability

Short sighted vision for increasing employment (e.g. Holcim)

Development at all cost mentality

Too growth oriented

Development Board hell bent on current economic model

Members self-interest, self-importance

Eliminate CEO and put in clear-thinking person

No vision, corporate thinking and structure, council structure

Centralised decision making

Centralised power of administration

Council sees a need to attract and assume power at the expense of community groups (e.g. rural water schemes or hall committees)

Should be due respect for democratic process

Lack of understanding of the real state of affairs and/or denial by council

Should think more about preservation and less about growth

Inflexible council rules

\section{Infrastructure/Economy}

Rail line not well utilised, Unused

railway station

High road accident rates

Holcim

No Farmers Market

\section{Local People and Attitudes}

Local attitude toward unsustainable development e.g. Holcim

Small minded attitudes

Division, conservative, conventional mindset

Resist change, reverse progress, consumerism

Small Town Parochial Attitude

Apathy, stupidity, greed for profit

Inability to adapt

Demographics: Absence of bright young people who can set new directions

Hard to form relationships

The time it takes to become a local

Local mindset and behaviour

Those seek to create Queenstown here, but with less than Ashburton budget

Expectation that others will solve our problems

Hard to stand out from the group

\section{Environment}

Intensive Dairy Farming, Growth of

Dairy Farming

Untidy harbour

Sea Level Rise, Oamaru too close to sea

level

Quality of Water

Overexploitation of groundwater

Water contamination by poor farming

methods

South Hill is too steep for biking 


\section{Stock Take 3 - Assets}

1. List natural resources available for Oamaru.

2. List your capabilities that others need.

3. List capabilities of several people you know that you need.

4. Can you think of three critical Infrastructure Assets?

\section{Natural Resources}

Oamaru Stone

Land, Good land. Agricultural hinterland

Good Soils, Totara soil, Climate. Hills

Sea, Ocean Wind, clean water, Waitaki

River, Clean Air, Beaches

Nice People, People and their skills

Timber, Fish, Forests, Wood

Coal,

Livestock. Penguin colony, Cows

Organic Food. Organic gardeners

Small group of highly motivated,

community-minded people

Historic precinct. Best built town in NZ + infrastructure

Rich social history + pride in community

Whiskey, Wine

\section{Capabilities:}

General:

Progressive thinkers

Brainpower

Ideas, Vision, Leadership, Pigheadedness

Care, Hope

Ability to compromise

Willingness to work hard without monetary reward

Generally positive outlook

Passion, conviction, energy

Understanding, Experience

Youth and Strength

Open-mindedness

Lateral Thinking, team leader, practical hand skills

Mentoring and Life Planning

Listening, Ideas, Technical Skills

Leadership through experience

Analytical
Good communication skills

Sustainable living skills

Belief in Palmerston

Inventor

Commitment to change ability

Agriculture and Food:

Gardening and Fruit Growing

Sheep Shearing

Farming knowledge, animal husbandry knowledge, Organic Farming

Knowledge of gardening

Vegetable growing education

Organic Market Gardeners

Highly skilled gardener

Food preservation knowledge, Food Storage

Knowledge about liquor

A real knack for producing alcoholic beverages

Food Technology Knowledge

Baking

Cooking

Ability to compost

Horticulture

Social/Organisation:

Organization, Leadership, Team, Management

People management skills

Communication and Organising skills

Planning

People Skills, help people to work together to help other people now and into future

Leadership, management, networking

Organised, good listener.

Organising ability 
Art \& Craft:

\section{Artists}

Book Binder

Sign writing,

Writing and Illustrating

Building, Sewing, Woodwork

Traditional Skills

Personal craft skills

Boot maker

Bag maker

Boat builder

Live theatre, good actors

194 other skills necessary for internal economy

Information Technology:

Computer Information Management

Computer skills

Computing,

Computer whizz

Education and Learning:

Maths, History, Politics (US)

Speak Japanese

Knowledge of history, cultures

Teaching and music

Medical/Health/Therapy:

Natural Health Practitioner

Doctor

Medical

Energy Clearing, Vibrational Therapy

Hospital surgeons

Science/Engineering/Construction

Mechanic, Builder

Engineering, technology

Hydraulic Analysis

Scientific Instrument builder

Construction skills, heavy construction

Car mechanic

Builder
Architecture

Practical skills: Building, Plumbing

Alternative Energy Knowledge

Trade Skills

\section{Critical Infrastructure:}

Water supply

Hospital, Health System

Rural water scheme

Electric Grid, Energy, Waitaki Dams (Ben

More), Electricity Supply

Telecommunications

Sewerage, Waste Disposal

Resource Recovery Park

Food availability, Food Supply

Transport of goods, Road Network

Shops

Harbour, Harbour architecture

Community Centre, Radio station

Historic fabric of the town

Volunteers clubs and groups

Libraries and museum

Water pumping station

Schools

Road and Rail, Bridges

Heating, Shelter

Hampden Energy Group

Organic Gardening Group

Aquatic centre

Historic precinct

Long-service buses

Power 


\section{Barriers to Change:}

\section{Social:}

Convincing community at large of need to change - "apathy, lethargy"

Belief that community is "clean and green"

Fear of change

Citizens attitudes/values to change

Negative public opinion

Social ties not strong enough

Failure of individuals and communities to

"hear" scientific evidence and commit to

needed charge

People's fear of more work and fewer

“convenient” products

Resistance by non-believers (the majority)

that there is no problem and greater interest

in growth money and consumption

Tree planting on private land would annoy

land owners

Lack of will from bulk of population - not

willing to take perceived backwards step

Fear. Greed. Ignorance. Ambivalence

Current psyche/religion/cosmology/belief

system

People still believe in model of progress + conventional method of doing business

Community not convinced of worth

Unwillingness to move from comfort zone

- "better the devil you know..."

Radicals represented as scare-mongers

If Oamaru is the only Transition Town in

NZ then everyone will want to move here severe stress to total carrying capacity and population

People too greedy + stupid + timid

Lack of acceptance by general public of

global issues i.e. [peak] oil, climate

[change], growth

People don't want change - are afraid to

lose something

Some people want profit over necessities

No valid reason why action now won't help our futures
Enough for people's need, not for people’s greed

Lack of 'buy in' from most locals

Habits. Resistance to change

Greed - everyone wanting more

Fear of losing out now despite benefit to

future generations

Present paradigm

Attitude

Little community spirit

Resistance to change

Perceived lack of freedom of choice

Fear of change

Disability preventing walking or cycling

Habits (tea, coffee, imports)

Fear of loss of "'” and independence

Lack of public acceptance of need to make transition measures

Public resistance to perceived cost or drop

in material standards

"Leader" [at forum] standing in front

instead of local knowledge

\section{Government/Regulatory:}

Local govt. must comply with National

Govt. criteria

Local govt. preoccupation with economic growth + dominance by CEO \& Mayor

WDC

Council attitudes/values to change

Requires legislative change for e.g. marine reserve - national govt. support

Negative political decision makers.

Powerful vested interests

Bureaucratic opposition

Failure of central govt. to create necessary

"' environment + incentives

Present legal \& political system would not recognise CCC rulings

Returning of containers is not presently

required - could overcome by cottage

industry accepting containers and re-filling

Political obstruction 
Our local council

Govt. legal regulations

Present bureaucracy - local + national

[Politicians] unwilling to risk unpopularity

Resentment of perceived control and overregulation

Attitude of local council

Current political climate

Some measures need law change by central govt.

Local community does not have the right to impose things like a charge/deposit on

containers

Govt/local council regulations

Central decision makers deny problem

Not yet political will

Not yet govt. will

\section{Economic/Financial:}

Money to pay the experts - "University" Oversees owners

Failure of govts. to substitute debt-based monetary system which needs growth Current economic/political structures have fossil-fuels built in - pricing, work load, etc
Financial markets

No money in it

Lack of finance

It would be seen as anti-profit and no

growth

Too much dependency and investment in the status quo - profits and greed

Increase in rates for changes

Ownership of key resources held by absent owners

Expensive (in all ways) printed guff

\section{Industry/Commercial:}

Manufacturers refusing to take back packaging

Corporate resistance and resulting political pressure on council

Attitude of big business

Resistance from large multi-nationals

Not yet industry will

\section{Other:}

NOTHING!

Purple pens, lights on, fan going. 


\section{Appendix H - Project Planning Exercise}

\section{Project Visioning:}

Give your project a descriptive title:

List no more than three objectives, or things that your project will do:

Make a project team charter to share, include names, contact details, skills, interests, time commitment available, suggested meeting times and roles in the team:

In five years time when your project has been successful - What is different? What is better? What new adaptations can people do? What new jobs exist? What harm has been reduced?

At the end of one year, what one thing would indicate that your project is on track?

\section{Project Shaping:}

\section{Barriers to Change:}

- Identify any possible barriers to your chosen activity being undertaken right now:

- What work could be done to eliminate those barriers?

2. Asset Identification:

- Identify any possible assets that would enable your chosen activity to be undertaken right now: (This includes you, your group and other people you think might get involved)

- What work could be done to activate those assets?

3. Expertise and Outside Assistance:

- Identify any experts or external help you would need to enrol to assist your chosen activity being undertaken right now:

- What work could be done to enrol that assistance?

\section{Government Assistance:}

- Identify any possible government assistance to enable your chosen activity to be undertaken right now:

- What work could be done to enable that assistance?

5. Livelihood Assessment:

- Identify any possible means by which someone could make a living from your chosen activity:

- What work could be done to enable those means?

\section{Project Planning:}

If there were no barriers, and you could use all the assets you need, map out the activities and time line for your successful project:

What is the first step in realising your project? What is the next thing your group will do, and set the date: 


\section{Transition Declaration of Independence}

Adapted from the Declaration of Independence of the United States of America Thomas Jefferson, 1776

Adaptation by Dr. Susan Krumdieck, 2008

When in the Course of human events it becomes necessary for one people to dissolve the economic bands which have connected them with another and to assume among the powers of the earth, the separate and equal station to which the Laws of Nature and of Nature's God entitle them, a decent respect to the opinions of mankind requires that they should declare the causes which impel them to the separation.

We hold these truths to be self-evident, that all people are created equal, that they are endowed by their Creator with certain unalienable Rights, that among these are Life, Liberty, Justice, the pursuit of Happiness, a Healthy Natural Environment and Sustainability.

- That to secure these rights, Organisations are instituted among Communities, deriving their just powers from the consent of the Members,

- That whenever any Form of Economy becomes destructive of these ends, it is the Right of the People to alter or to abolish it, and to institute a new Relationship, laying its foundation on such principles and organizing its powers in such form, as to them shall seem most likely to effect their Safety and Happiness. Prudence, indeed, will dictate that Economic Relationships long established should not be changed for light and transient causes; and accordingly all experience hath shown that mankind are more disposed to suffer, while evils are sufferable than to right themselves by abolishing the forms to which they are accustomed. But when a long train of abuses and usurpations, pursuing invariably the same Object evinces a design to reduce them and their environment to ruin, it is their right, it is their duty, to throw off such Economic Constraints, and to provide new Guards for their future security and sustainability.

- Such has been the patient sufferance of this community; and such is now the necessity which constrains us to alter our former Systems of Business Growth for its own Sake and Environmental Exploitation. The history of the present Theory of Economics is a history of repeated disasters, injuries and usurpations, all having in direct object the establishment of an absolute Tyranny over communities and the environment. To prove this, let Facts be submitted to a candid world.

The Growth Economy for its own Sake has plundered our seas, ravaged our coasts, felled our forests, polluted our water and fouled our air

The Growth Economy for its own Sake has exploited our talents, put us into debt, degraded our culture and eroded our relationships with the members of our community.

The Growth Economy for its own Sake has exploited mineral resources which by right should belong to people in perpetuity in order to obscenely enrich a few in the short term.

The Growth Economy for its own Sake has paved our farms, sprawled our towns, and destroyed the quality of live of our people and their children and grandchildren.

The Growth Economy for its own Sake has convinced us, for more than a century, to ignore the voice of scientific knowledge and reason in order to continue the acidification of our air and oceans through Sulphur Dioxide, Nitrous Oxides and Carbon Dioxide emissions from combustion of fossil fuels.

The Growth Economy for its own Sake has exploited the labour of people and environments that have no protection from ill use, and has persecuted people who worked for economic justice and equality.

The Growth Economy for its own Sake has assaulted the morality of our youth and treated them as a target market rather than with the respect of future citizens and community members.

The Growth Economy for its own Sake has corrupted the purpose of our governance and civic institutions, it has usurped the purpose of our curiosity and research efforts, and it has shifted the motivation for the education of our young from development of their intellect and character to exploitation of their labours for further growth of the economy.

We, therefore, the Representatives of the Transition Community, Assembled, appealing to the Supreme Judge of the world for the rectitude of our intentions, do, in the Name, and by Authority of the good People of this community, solemnly publish and declare, That this Community is, and of Right ought to be Free, that we are Absolved from all unsustainable and perverse requirements of the Exponential Growth Economy, and that all connection between this Community and the Exponential Growth Economy, is and ought to be totally dissolved; and that as a Free and Sustainable Community, we have full Power to reduce fuel and electricity consumption, restore our environment, protect our culture, nurture our agricultural assets, set aside our resources, refrain from extracting minerals, stone or fossil fuels at exponential rates, set our own inviolate limits to growth and pollution of our natural environment, conclude Peace, contract Alliances, establish Local Commerce based on our own principles and theories, and to do all other Acts and Things which Sustainable Communities may of right do.

- And for the support of this Declaration, with a firm reliance on the protection of Divine Providence, we mutually pledge to each other our Lives, our Fortunes, and our sacred Honor. 


\section{Appendix I - Feedback Questions:}

\section{Feedback Responses:}

1. Content - How did you feel about the 2. Participation - How did you feel about amount of information provided during the structure and level of participation of the weekend forum?

the weekend forum?
1. Too much $-0 / 23$
$2 . \quad 2 / 23$
3. Just right $-18 / 23$
4. $3 / 23$
5. Too little $-0 / 23$
1. Too structured - $\quad 1 / 19$
2 . $3 / 19$
3. Just right - $\quad 12 / 19$
4 . $\quad 3 / 19$
5. Too open - $\quad 0 / 19$
1. No participation - $0 / 17$
$2 . \quad 0 / 17$
3. Some participation $-4 / 17$
$4 . \quad 6 / 17$
5. Full participation $-7 / 17$

3. Motivation - How did the weekend forum leave you feeling about the future?
1. Less positive

\section{$1 / 22$}
$0 / 22$
3. Same
$2 / 22$
4.

$$
4 / 22
$$
4. More positive
$15 / 22$
$\begin{array}{ll}\text { 1. Less empowered } & 0 / 20 \\ \text { 2. } & 0 / 20 \\ \text { 3. Same } & 1 / 20 \\ \text { 4. } & 9 / 20 \\ \text { 5. Empowered } & 10 / 20\end{array}$

4. Learning - How much do you think you learned this weekend?

$\begin{array}{ll}\text { 1. Nothing new } & 0 / 20 \\ \text { 2. } & 2 / 20 \\ \text { 3. Some } & 6 / 20 \\ \text { 4. } & 8 / 20 \\ \text { 5. Heaps } & 4 / 20\end{array}$

5. Enjoyment - How did you feel about the weekend forum?
1. Did not enjoy $\quad 0 / 22$
$2 . \quad 0 / 22$
3. Average $\quad 1 / 22$
$4 . \quad 5 / 22$
5. Really enjoyed $\quad 16 / 22$

6. Communication - How well did you feel the weekend forum let you express your opinions?
1. Really badly
$0 / 22$
2.
$1 / 22$
3. Average
$8 / 22$
4.
$6 / 22$
5. Really well
$7 / 22$

7. Tools and Aides - How did you feel about the presentation methods and visioning aides?
1. Useless $\quad 0 / 22$
$2 . \quad 1 / 22$
3. Fine $\quad 2 / 22$
4 . $\quad 7 / 22$
5. Great 12/22 